\title{
SIX DECADES OF RADIOCARBON DATING IN NEW WORLD ARCHAEOLOGY1
}

\author{
R E Taylor \\ Department of Anthropology, University of California, Riverside, California 92521, USA; Cotsen Institute of Archaeology, \\ University of California, Los Angeles, California 92511, USA; Keck Carbon Cycle Accelerator Mass Spectrometry Labora- \\ tory, Department of Earth System Science, University of California, Irvine, California 92697, USA. Email: retaylor@ ucr.edu.
}

\begin{abstract}
Radiocarbon $\left({ }^{14} \mathrm{C}\right)$ dating provided New World archaeological research with the first continent-wide common chronometric scale that transcended the mostly relative site- and region-specific chronological sequences that had been assembled during the preceding century of fieldwork. ${ }^{14} \mathrm{C}$ data continue to play a critical role in establishing a chronometric framework for the 5-century-long debate concerning the timing of the initial peopling of the New World. Other issues where ${ }^{14} \mathrm{C}$ results have been of particular importance include the origins and development of New World agriculture and determination of the relationship between the Western and Classic Maya long-count calendar. The introduction of a third-generation measurement technology of accelerator mass spectrometry (AMS) beginning in the late 1970s has provided a means of obtaining analyses on milligram and microgram amounts of carbon permitting more detailed critical approaches to increasing the accuracy of ${ }^{14} \mathrm{C}$ values on certain sample types-particularly human skeletal materials. It also provided a more effective means of allowing greater dating precision in situations where such data had an important bearing on the validity of inferences about the rates of cultural evolutionary change in New World societies.
\end{abstract}

\section{INTRODUCTION}

For many archaeologists who had pursued their field studies in the pre-World War II and thus preradiocarbon period, ${ }^{14} \mathrm{C}$ dating quickly came to be recognized as one of the most important, if not the most important, single development in the entire 20th century history of the discipline. It was viewed by archaeologist and historian of archaeology Glyn Daniel as comparable in significance to the 19th century discovery of the geological antiquity of the human species (Daniel 1967:266). Those who were professionally active when it was introduced well understood that ${ }^{14} \mathrm{C}$ dating literally "transformed their understanding of the past, helping archaeologists to establish for the first time a reliable chronology of world cultures" (Renfrew and Bahn 2007:112). Few would contest the view of J Desmond Clark (1979:7) that without the "Radiocarbon Revolution" (Renfrew 1974), prehistorians would still be "foundering in a sea of imprecisions sometimes bred of inspired guesswork but more often of imaginative speculation." This is despite the initial, sometimes profoundly negative reactions of some archaeologists and others to specific initial ${ }^{14} \mathrm{C}$ values when these age determinations failed to confirm their long-held views (e.g. Neustupný 1970; cf. Taylor 2000b).

With specific reference to New World archaeological studies, the introduction of the ${ }^{14} \mathrm{C}$ method occurred at the very beginning of the post-World War II period of major expansion in the number of North American professional archaeologists. In the preceding 4 to 5 decades, a relatively small number of archaeologists working in the New World had slowly built up from hundreds of sites and local sequences with what Willey (1978:516) characterized as "archaeologically independent" relative chronological sequences, in most cases based on stratigraphy, seriation, and artifact cross-dating (Lyman and O'Brien 2006). ${ }^{14} \mathrm{C}$ determinations were most valuable when they could be clearly associated with specific components of existing chronological phases to provide potentially chronometric ("real" or solar time) equivalent frameworks to what had previously been relative sequences. Problems in how associations of the ${ }^{14} \mathrm{C}$-dated samples with archaeologically-defined features or

${ }^{1}$ This paper represents an updated and expanded review based on a discussion that previously appeared a decade ago in Radiocarbon (Taylor 2000a).

(C) 2009 by the Arizona Board of Regents on behalf of the University of Arizona Celebrating 50 Years of Radiocarbon

RADIOCARBON, Vol 51, Nr 1, 2009, p 173-212 
artifacts were documented became quickly evident. These issues continue to be the occasion of much discussion in the early 21 st century.

In the New World, only in southern Mesoamerica did there exist a complex calendar associated with a fully-formed writing system, which provides modern scholars with fixed chronometric reference points in the Maya lowland and several adjacent areas for a period, using Western calendar notation equivalents, from about AD 300 to 900 (Thompson 1971). ${ }^{2}$ Beginning in the 1930s, dendrochronological studies in parts of the southwestern United States permitted chronometric determinations to be assigned to many archaeological contexts in that region (Nash 2000). For the 3 to 4 centuries immediately preceding the European arrival in Mesoamerica and a limited number of other regions, ethnohistoric documentation could be pressed into service to provide limited chronometric information (Cline 1972). In some cases, linguistic evidence was employed to provide hypotheses concerning prehistoric chronological relationships, but many general questions were raised concerning the precision of inferences based on rates of linguistic change (Swadesh 1952; Renfrew et al. 2000). Unfortunately, all of these chronometric elements were available for a very small part of the New World for very limited temporal intervals. ${ }^{14} \mathrm{C}$ time became the principal prehistoric chronometric timescale for most of the Western Hemisphere for most of the period that human populations had inhabited this part of the world.

For some who began their academic or professional careers in the ${ }^{14} \mathrm{C}$ period, i.e. in the late $1950 \mathrm{~s}$ and beyond, ${ }^{14} \mathrm{C}$ dating came to be viewed as the routine means of dating a site or artifact. For a few field archaeologists belonging to that generational cohort, ${ }^{14} \mathrm{C}$ dating was regarded as a "black box" from which chronometric chronology was derived - a sample goes in, something "mysterious" happens in a far away laboratory, and a "date" comes out (Nash and Dean 2000:4). As will be noted below, that approach, in certain situations, contributed to creating at best, an incomplete, and, at worst, a completely erroneous understanding of some parts of the archaeological record. In some cases, it took as much as an entire decade and a major commitment of resources to correct significant errors in understanding the cultural history for a particular site or region, which had been based initially on 1 or $2{ }^{14} \mathrm{C}$ determinations. At the same time, fortunately, there was the realization by many archaeologists that the chronometric data provided by ${ }^{14} \mathrm{C}$ needed to be examined as critically and in much detail as statigraphic profiles, seriation tables, and the sometimes complex geological, biological, and other environmental contextual data.

Over the now more than 60 -yr history of ${ }^{14} \mathrm{C}$ research, the different technologies employed to measure ${ }^{14} \mathrm{C}$ have influenced the feasibility of obtaining accurate measurements on certain sample types as well as the typical precision that could be achieved. For the first 3 decades following the introduction of the method, decay counting technology—initially with solid carbon until it became obsolete in large part because of the effect of artificial or "bomb" ${ }^{14} \mathrm{C}$ in nuclear fallout, and then various types of gas proportional and liquid scintillation systems-imposed constraints both in terms of the routine sample sizes typically required as well as the effective measurement precision routinely achievable (Taylor 1987:71-104).

\footnotetext{
${ }^{2}$ Currently, the earliest known long-count date for southern Mesoamerica is recorded on Stela 2 at the Olmec site of Chiapa de Corzo, Chiapas, Mexico. Using the GMT correlation, the equivalent date in the Western calendar would be $36 \mathrm{BC}$. The earliest long-count date from the Lowland Maya region is recorded on Stela 29 at Tikal, which in the GMT correlation would be AD 292 in the Western calendar. The last known recorded long-count data was inscribed on Monument 101 at the site of Tonina in Chiapas. Assuming the GMT correlation, the equivalent Western calendar date would be AD 909 (Taube K, personal communication, 2009).
} 
With the introduction of accelerator mass spectrometry (AMS) technology in the late 1970s and its rapid expansion in its application to the ${ }^{14} \mathrm{C}$ dating of archaeological samples in the mid-1980s and beyond, these constraints have been largely removed (Duplessy and Arnold 1989; Taylor 1992). In the early 21st century, AMS technology has continued to flourish with the use of AMS instrumentation to measure many additional rare isotopes in addition to ${ }^{14} \mathrm{C}$ and with many areas of oceanographic, geochemical, astrophysical, nuclear chemistry, and biological research benefiting from its analytical power (Knezovich et al. 2007). In the ending decades of the 20th century and first decade of the 21 st century, as the current senior generation of ${ }^{14} \mathrm{C}$ researchers retired, operations of many of the existing decay counting laboratories have been discontinued. In most cases, members of the younger generation of investigators are undertaking research at existing and new AMS facilities.

Alongside the development of AMS-based ${ }^{14} \mathrm{C}$ measurement capabilities, the other major advancement in ${ }^{14} \mathrm{C}$ research, particularly within the last 2 decades, has been increasingly precise detailing of short-term "wiggles" or "warps" [de Vries effects] in the Holocene ${ }^{14} \mathrm{C}$ timescale based on expanded tree-ring records. There has also been an extension by several thousand years into the terminal Pleistocene of the capability to calibrate the ${ }^{14} \mathrm{C}$ timescale. Prior to that, there is the capability to compare ${ }^{14} \mathrm{C}$ values with age estimates based on other dating [e.g. U-series] and temporal incrementing methods [e.g. ice cores and varved sediments] (Bronk Ramsey et al. 2006). Research which sought to understand the relationship between ${ }^{14} \mathrm{C}$ time and solar or "real" time began within a decade of the introduction of ${ }^{14} \mathrm{C}$ dating (de Vries 1958; Willis et al. 1960), and thus ${ }^{14} \mathrm{C}$ calibration studies have now been underway for almost 5 decades. ${ }^{3}$

The importance of developing a means of calibrating ${ }^{14} \mathrm{C}$ values in light of documented offsets from solar time was initially of more concern in contexts where non-historic archaeological chronologies were linked with historic calendar-based chronologies such as the purported linkages based on artifact crossdating between Central/Western European and Aegean archaeological sequences and those of historic Egypt (Renfrew 1974). In the Western Hemisphere, except for the Lowland Maya and parts of adjacent regions, such a situation did not exist, and thus for most New World prehistoric culture history studies, chronometric time and ${ }^{14} \mathrm{C}$ time might have been considered as functionally synonymous.

However, over the last 2 decades, with the increasing precision of the ${ }^{14} \mathrm{C}$ measurements defining Holocene short- and medium-term de Vries effects, the application of quantitative protocols to calculate ${ }^{14} \mathrm{C}$ offset values based on the input of range of variables (including uncertainties associated with the ${ }^{14} \mathrm{C}$ value being calibrated and the uncertainties of the calibration values themselves), and the general availability of microcomputer-based software developed by different investigators to carry out routine calculations, there has developed among many New World archaeologists a tradition that ${ }^{14} \mathrm{C}$ values should be calibrated.

There are certainly a number of archaeological questions and problems for which calibrated ${ }^{14} \mathrm{C}$ values are required. For example, questions about the degree of temporal overlap of $2{ }^{14} \mathrm{C}$-dated archaeological expressions do indeed require calibrated ${ }^{14} \mathrm{C}$ values. Comparisons of ${ }^{14} \mathrm{C}$-based chronolo-

\footnotetext{
${ }^{3}$ In the late 1950 s and early $1960 \mathrm{~s},{ }^{14} \mathrm{C}$ determinations on presumably well-documented Egyptian archaeological samples from the 2nd millennium BC began to yield ages that were consistently too young by as much as $600-800$ yr. The initial response to these data by Libby was that the conventional Egyptian chronology for the Old Kingdom period (about 3000$2200 \mathrm{BC}$ ) was in error rather than there was any systematic offset in the ${ }^{14} \mathrm{C}$ values (Libby 1967). Measurements obtained by a number of investigators throughout the 1960s, primarily on dendrochronologically-dated wood samples eventually spanning 6 to 7 millennia, provided the initial definitive evidence that it was, in fact, the ${ }^{14} \mathrm{C}$ values for much of the Holocene that were offset from "real" or solar time (e.g. Suess 1961, 1965; Stuiver 1970).
} 
gies with those derived from Maya calendar calculations would also require calibration. In addition, there would be situations where comparisons with other chronometric techniques that render their age values, at least potentially, in solar time would obviously require the ${ }^{14} \mathrm{C}$ values also to be calibrated. However, it is not clear why, in general, expressions of chronometric time for the vast majority of archaeological applications of ${ }^{14} \mathrm{C}$ data in New World archaeology should not be simply expressed in ${ }^{14} \mathrm{C}$ time. In accordance with such an understanding, this discussion will express ${ }^{14} \mathrm{C}$ age determinations in terms of "BP," i.e. ${ }^{14} \mathrm{C}$ years before 1950 (Stuiver and Polach 1977).

Except for the discussion of the Paleoamerican (Paleoindian) period focused on North America, the treatment of this topic will be considered on a regional basis divided into eastern, western, and southwestern North America, Mesoamerica, and South America. Two case studies-the dating of the Kennewick skeleton for North America and the dating of the site of Monte Verde, Chile, in South America-provide 2 specific examples of the several types of issues that ${ }^{14} \mathrm{C}$ dating evidence has been called upon to resolve in New World archaeological studies. Since there are now literally hundreds of sites in the New World for which ${ }^{14} \mathrm{C}$ age determinations have provided chronometric time frames, we obviously will only be able to address a small fraction of them. In this discussion, we will focus attention on various elements in the evaluation ${ }^{14} \mathrm{C}$ data in various sites and contexts that illustrate general issues that arise in the critical utilization of the ${ }^{14} \mathrm{C}$ technique in New World archaeological contexts.

\section{WILLARD LIBBY AND NEW WORLD ARCHAEOLOGY}

The origins and initial development of the ${ }^{14} \mathrm{C}$ method can be viewed to a considerable degree as the result of what would, in later decades, be characterized as "interdisciplinary" scientific investigations (de Messieres 2001). Appendix I briefly reviews several technical elements of that process. Willard Frank Libby [1909-1980], the physical and nuclear chemist who was responsible for the method's formulation and foundational experimental confirmation, once described himself as an "amateur archaeologist" (Libby in Olsson 1970:107). While this might be best considered as one of his rare moments of public humor, an examination of the corpus of ${ }^{14} \mathrm{C}$ dates measured at his laboratories at the University of Chicago, and later at the University of California, Los Angeles (UCLA), demonstrated his interest in archaeology. ${ }^{4}$ For example, of the $381{ }^{14} \mathrm{C}$ published determinations obtained during the 6-yr operation (1947-52) of his Chicago laboratory, 242 (or about 65\%) were obtained on archaeologically-related samples. Of these 242 archaeological samples, 167 , or almost $70 \%$ of the dates, were obtained on samples from New World archaeological sites. Of the New World archaeological samples, over $75 \%$ were run on North America samples. ${ }^{5}$ Libby's avocational interest in archaeology would continue throughout his illustrious scientific career with a specific

\footnotetext{
${ }^{4}$ In a letter written in 1947, Libby commented that one of the reasons he chose James Arnold as a collaborator in his research on ${ }^{14} \mathrm{C}$ dating was the fact that Arnold, although a physical chemist, had "a real interest in Egyptian archaeology" (Libby quoted in Marlowe 1980:1008). Arnold's father, although a corporate attorney, was particularly knowledgeable in Egyptian archaeology, serving for many years as the American Secretary for the British-based Egypt Exploration Society (Arnold 1992).

${ }^{5}$ The committee that Libby assembled to assist in the selection of unknown age samples to date might also have influenced the imbalance in the number of samples dated from the New World and especially North America. Of the 16 collaborators, 7 were involved in obtaining archaeological samples from the United States and Canada. Regretfully, there is, as yet, no publication that comprehensively lists all of the ${ }^{14} \mathrm{C}$ dates measured by Libby's UCLA laboratory during its operation from 1969 to about 1995. Based on a preliminary survey of the records of that laboratory by the author of this article, it is estimated that approximately $70 \%$ of the UCLA dates were obtained on archaeologically-related samples.
} 
interest in the dating of New World "Early Man" sites, i.e. sites where evidence for pre-Holocene human populations in the Western Hemisphere was being advanced. ${ }^{6}$

One year prior to the award of his Nobel Prize (1960), Libby had joined the UCLA faculty as Professor of Chemistry and, soon following, as Director of the Institute of Geophysics and Planetary Physics (IGPP). ${ }^{7}$ As had been the case at Chicago, a sizable proportion of samples measured at the UCLA radiocarbon laboratory-officially the UCLA Isotope Laboratory—related to archaeological sites and topics (Berger 1992). The work of Rainer Berger and others at this laboratory on increasing the accuracy of the ${ }^{14} \mathrm{C}$ dating of bone samples was, in large part, stimulated by Libby's interest in providing direct dating on human skeletal remains from purported Pleistocene age New World human skeletons (Berger et al. 1964). Another outgrowth of Libby's interest in archaeology was his active support of several UCLA archaeology graduate students who served as Graduate Research Assistants in his laboratory. ${ }^{8}$

In large measure because of Libby's concerns about the ability to obtain valid ${ }^{14} \mathrm{C}$ dates on marine shell and organics in ceramics, one of the earliest studies of the ${ }^{14} \mathrm{C}$ reservoir age effects on Pacific coastal marine shells were undertaken (Berger et al. 1966; Taylor and Berger 1967). To convince Libby that valid ${ }^{14} \mathrm{C}$ ages could be obtained on organics contained in ceramics, an early study of that issue was also undertaken in his laboratory (Taylor and Berger 1968). As will be noted elsewhere, Libby's encouragement and support of excavations at the Tule Springs site in Nevada, his friendship with the African prehistorian L S B Leakey, and the subsequent involvement of his laboratory in the Calico site in California, derived from his interest in dating the earliest appearance of human populations in the New World.

Given this background, it is thus not surprising that important issues in New World archaeology to which early ${ }^{14} \mathrm{C}$ data were of particular significance included the dating of the earliest peopling of the Western Hemisphere, which included an interest in providing chronometric dates defining the Pleistocene/Holocene transition. For North America, this would include dates on the Two Creeks forest in Minnesota, which defined the terminus of the Pleistocene period in North America and would thus be of significant interest, as well, to Pleistocene geologists (Broecker and Farrand 1963; Leavitt and Kalin 1992). Other early topics addressed by samples measured in Libby's Chicago laboratory included the age of the Adena and Hopewell cultures in the Ohio Valley of eastern North America, the beginnings of New World agriculture in ancient Mesoamerica, and the correlation of the ancient Maya calendar with the Western calendar (Johnson 1965). Of that list of topics, provid-

\footnotetext{
${ }^{6}$ A possible initial source of Libby's avocational interest in archaeology was mentioned to the author by James Arnold (Arnold, personal communication, 2005). According to Arnold, at the legendary parties hosted by Libby and his faculty colleagues at the University of Chicago in the late 1940s and early 1950s, a topic of half-serious conversation often raised by Libby revolved around the possibility that very ancient technologies had once existed and then had been lost. The only way to examine that possibility would be through archaeology. Arnold recalled that his "first memory of hearing about the $\left[{ }^{14} \mathrm{C}\right]$ dating idea" was at one of these parties at Libby's home in late 1946 (Arnold 1992:4).

${ }^{7}$ Between October 1954, when he left the University of Chicago, and June 1959, when he jointed the faculty of the University of California, Los Angeles, Libby served as a Commissioner of the US Atomic Energy Commission (AEC), predecessor of the current US Department of Energy, having been appointed by President Eisenhower to this position. Continuing his work, which had begun with the Manhattan Project during World War II, he had maintained direct involvement in US atomic energy development at the AEC from the time the commission had been established, serving as a member of its General Advisory Committee. While at the AEC, he organized Project Sunshine, a study of radioactive fallout debris from nuclear weapon's testing in the atmosphere (Buck 1983). It was his access to classified information concerning the magnitude of the fallout from "bomb" ${ }^{14} \mathrm{C}$ that alerted him to the problem that this fallout would create for solid carbon counting.

${ }^{8}$ In the interest of full historical disclosure, the author of this article was the first of these graduate students in the UCLA Isotope Laboratory.
} 
ing a timescale for the founding human populations occupying the Western Hemisphere continues as an active source of both significant interest and contentious dispute as we begin the second decade of the 21 st century.

\section{PALEOAMERICAN}

The longest running debate in New World archaeology continues to be the nature and timing of the arrival of human populations in the Western Hemisphere during the terminal Pleistocene (Fiedel 2000, 2004a,b, 2006; Meltzer 2004; Goebel et al. 2008). Perhaps the only now universally accepted understandings are that the origin of genus Homo is to be found outside of the New World and that sometime late in the Pleistocene, small bands of anatomically modern Homo sapiens hunters and gatherers migrated from some place in the Old World to the Western Hemisphere (Nitecki and Nitecki 1994).

In this discussion, we shall use the term "Paleoamerican" in place of the traditional "Paleoindian" to refer to studies that seek to document how and when these populations found their way to the American continent (Bonnichsen et al. 2005). The use of this term reflects the increasing evidence that an unknown number of these late Pleistocene or early Holocene New World human groups may represent one or more extinct New World populations who are not genetically related to any contemporary Native American group (Fagundes et al. 2008).

No matter what terminology is employed, there is no question that the advent of ${ }^{14} \mathrm{C}$ dating completely transformed discussions concerning dating frameworks for sites and contexts associated with the earliest human groups that occupied the Western Hemisphere (Wilmsen 1965; Taylor 1991; Faught 2008). The history of the application of ${ }^{14} \mathrm{C}$ in New World Paleoamerican research provides some classic illustrations of problems created when there is insufficient attention to critically analyzing the relationship of archaeological features with environmental-most importantly geological-contexts from which samples on which ${ }^{14} \mathrm{C}$ data were obtained and which were intended to date specific archaeological features.

Late 20th century discussions of this topic can trace their origins to the 1930s and the general acceptance of the direct association of the 2 types of fluted projectile points-Clovis and Folsom-with skeletal remains of an extinct North American megafauna, particularly mammoth and an extinct species of bison. These discoveries convinced the professional archaeological community of that time that human populations had entered the New World sometime between 25,000 and 10,000 yr ago (Wormington 1957). In the pre- ${ }^{14} \mathrm{C}$ era, this range in the age assigned to the entry resulted primarily from differences among Pleistocene geologists and others as to the chronometric placement of the final phase of the terminal Pleistocene North American Wisconsin glaciation and the timing of the disappearance of the North American Pleistocene megafauna. By about 1940, on stratigraphic grounds, Clovis was demonstrated to have predated Folsom, but the temporal offset was unknown (Meltzer 1989).

One of the earliest samples dated by the Chicago ${ }^{14} \mathrm{C}$ laboratory concerned the resolution of the chronological status for Folsom materials. In pursuing this question, and in later considerations of the question involving the dating of the Clovis and then purported pre-Clovis occupations in the New World, several issues that routinely confront the critical application of ${ }^{14} \mathrm{C}$ in archaeology have been very well illustrated. For example, the problem of stratigraphic association of an organic sample (e.g. charcoal) for which a ${ }^{14} \mathrm{C}$ age estimate is obtained and an archaeological or geological context was vividly exemplified in the first ${ }^{14} \mathrm{C}$ age determination on a sample from the Folsom type site in New Mexico. 
The sample thought to be associated with the Folsom point, initially described as charcoal from a firepit situated below bison bones and artifacts collected in 1933 by Harold J Cook [1887-1962], was dated by the Chicago laboratory at $4283 \pm 250 \mathrm{BP}$ (C-377), based on an average of 2 determinations of $4575 \pm 300 \mathrm{BP}$ and $3923 \pm 400 \mathrm{BP} .{ }^{9}$ This result prompted the terse comment "surprisingly young" (Arnold and Libby 1950:10). Cook revisited the Folsom type site in June 1950. His restudy of the geological context concluded that the original "sample [used for the ${ }^{14} \mathrm{C}$ measurement] had been taken from a hearth in the fill of a secondary channel which had cut through the original deposit of bison bone and artifacts" (Roberts 1951:116). A ${ }^{14} \mathrm{C}$ value of $9883 \pm 350 \mathrm{BP}(\mathrm{C}-558)$ was subsequently obtained on burned bison bone from what was interpreted as the Folsom horizon at Lubbock Lake, Texas (Libby 1951:293). Thus, the first ${ }^{14} \mathrm{C}$ determination concerned with one of the most controversial issues in American archaeology was deemed unacceptable for what it was supposed to have dated, requiring reinterpretation of the geological context and an additional ${ }^{14} \mathrm{C}$ analysis on a sample in presumed direct contextual relationship with the cultural or technological tradition for which dating was being attempted (Roberts 1951:20-21; Haynes et al. 1992:384; Meltzer et al. 2002).

It was subsequently proposed that the problem may have not been resolved by the Lubbock Lake ${ }^{14} \mathrm{C}$ value. Geological evidence combined with additional ${ }^{14} \mathrm{C}$ data pointed to the conclusion that the burned bone sample used for C-558 did not, in fact, come from the Folsom levels at the Lubbock Late site (Haas et al. 1986; Holliday and Johnson 1986). If this is correct, the first ${ }^{14} \mathrm{C}$ age determination securely associated with Folsom materials was obtained on charcoal collected at the Lindenmeier site in Colorado on which was obtained a ${ }^{14} \mathrm{C}$ value of 10,780 $\pm 135 \mathrm{BP}$ [I-141] (Haynes and Agogino 1960; Walton et al. 1961).

Over the next 5 decades, a steadily increasing corpus of ${ }^{14} \mathrm{C}$ determinations has been obtained on materials associated with various degrees of confidence with a number of Clovis and Folsom sites in North America. Beginning in the mid-1960s (Haynes 1965), there has been a series of summaries and reviews of ${ }^{14} \mathrm{C}$ values on various sample materials that are, or are purported to be, in secure stratigraphic relationship with Clovis or Folsom occupations. Based on critical analyses of these data in Haynes (1992) and Taylor et al. (1996), it appears that Clovis populations hunted and collected on the North American Great Plains from about 11,600 to 10,900 BP, while Folsom groups flourished from about 11,000 to 10,250 BP. The transition from Clovis to Folsom may have occurred within a period of $100{ }^{14} \mathrm{C}$ yr or less (Haynes 1984, 1991a), although the current suite of dates lacks the precision required to critically test this assertion and a late Pleistocene plateau in the ${ }^{14} \mathrm{C}$ timescale complicates calibration.

Waters and Stafford (2007) have presented what they view as a "more accurate time span for Clovis" based on their selective evaluation of the existing ${ }^{14} \mathrm{C}$ values and additional ${ }^{14} \mathrm{C}$ determinations. Their reinterpretation of the ${ }^{14} \mathrm{C}$ data revised the Clovis time range to between about 11,050 to 10,800 BP. This reevaluation reduced the maximum age for Clovis in North America by approximately 500 yr. On this basis, they argue that this positions the Clovis cultural complex in North American sites essentially contemporaneous with other non-Clovis sites in both North and South America. They view their data and arguments as providing support for the view that pre-Clovis human populations were already present in the New World prior to Clovis peoples becoming visible in the archaeological record. Fifteen archaeological and geological specialists in Paleoamerican

\footnotetext{
${ }^{9} \mathrm{~A}$ conventional calculation of a weighted average for the 2 independently determined duplicate values of $4575 \pm 300 \mathrm{BP}$ and $3923 \pm 400 \mathrm{BP}$ should produce a value of $4340 \pm 240 \mathrm{BP}$, not $4283 \pm 250 \mathrm{BP}$. The mathematical approach taken by Libby in calculating weighted averages based on multiple measurements on the same sample is not currently known to this writer. He has not been able to locate any statement or citation in Libby's ${ }^{14} \mathrm{C}$ papers as to the formula used to calculate weighted averages from counting data.
} 
research questioned the arguments used by Waters and Stafford, including those which disregarded ${ }^{14} \mathrm{C}$ values older than $11,050 \mathrm{BP}$. This group concluded that "[o]nly a continuing program of radiometric dating and careful stratigraphic correlations can address the lingering ambiguity about the emergence and spread of Clovis culture" (Haynes et al. 2007).

The critical influence of ${ }^{14} \mathrm{C}$ dating on New World Paleoamerican studies can be seen most clearly when it is noted that in several cases, a single ${ }^{14} \mathrm{C}$ age determination was the most important factor in directing greatly increased attention along, in some cases, with relatively massive amounts of funding and other resources toward specific sites and regions purported to contain evidence of archaeological materials presumed to be older than Clovis. For example, in the early 1960s, the decision to undertake large-scale excavations at Tule Springs, Nevada (Wormington and Ellis 1967) was stimulated in large part by a single ${ }^{14} \mathrm{C}$ determination of $>23,000 \mathrm{yr}$ (C-914) obtained by Libby's Chicago group (Libby 1952:121). The sample analyzed was characterized as "charcoal" recovered from what had been labeled a "hearth-like feature" by excavators who associated its occurrence with sediments containing the bones of extinct fauna (Harrington 1954; Harrington and Simpson 1961).

In another instance, $\mathrm{a}^{14} \mathrm{C}$ age of $27,000^{+3000}{ }_{-2000} \mathrm{BP}$ (Irving and Harrington 1973) was obtained on an inorganic fraction of a bone implement recovered from a locality in the Old Crow Basin, Yukon Territory, Canada (Irving 1985:547). At both Tule Springs and in the case of the Old Crow artifact, subsequent ${ }^{14} \mathrm{C}$ data determined that the original age assignments for the cultural materials had been greatly inflated. In the case of Tule Springs, the only uncontested artifacts recovered during extensive excavations carried out in the early 1960s were associated with sediments dating in the 10,000 to $11,000 \mathrm{BP}$ range. The features originally labeled as "hearths" containing "charcoal" were determined to be concentrations of decayed plant remains associated with water channel or spring deposits (Haynes et al. 1966; Haynes 1988). For this site, the detailed attention to the specifics of the geological contexts of the purported archaeological materials and a critical evaluation of the ${ }^{14} \mathrm{C}$ values provided by the project geologist, C Vance Haynes Jr, provided a classic illustration of the need for geoarchaeological expertise if a critical and comprehensive evaluation of the integrity of site contexts is to be obtained in the study of a Paleoamerican site and the ${ }^{14} \mathrm{C}$ values are to be correctly assigned to the appropriate geological and/or archaeological contexts (Haynes 1967). As for the alleged 27,000-yr-old Old Crow implement, an organic fraction of the bone later yielded an AMSbased ${ }^{14} \mathrm{C}$ value of $1350 \pm 150 \mathrm{yr}$ (Nelson et al. 1986).

The extensive excavations carried out at Tule Springs in the early 1960s represented an early example in New World archaeology of prior planning to obtain a large suite of ${ }^{14} \mathrm{C}$ dates during the period that the excavations were underway. In many cases, the time interval that elapsed between the actual collection of a sample in the field, the determination of the ${ }^{14} \mathrm{C}$ age of that sample in the laboratoryin this case, Libby's UCLA Laboratory-and the communication of the age to archaeologists or geologists at the site was less than 10 days. In several cases, a sample collected on a Tuesday at Tule Springs was chemically pretreated on Wednesday at the UCLA laboratory, combusted on Thursday, counted on Friday and Saturday, and the results reported to the site on the following Monday. In several cases, the individual who collected the sample in the field and the individual who carried out the preparation of the sample in the laboratory was the same person. ${ }^{10}$ Within a period of about 15 months, 59 samples from Tule Springs or sites associated with the Tule Springs research were pro-

\footnotetext{
${ }^{10}$ In the interest of full historical disclosure, the author of this article was the individual who, as a UCLA graduate student, both collected a series of samples in the field at Tule Springs and processed them at the UCLA Isotope Laboratory. In the introductory section of the Tule Springs site report (Shutler 1967), there is a minor typographical error in the spelling of the name "Irwin Taylor." It should have been "Ervin Taylor." In addition to the UCLA Isotope Laboratory processed samples, C Vance Haynes, Jr processed samples from the Tule Springs site at the University of Arizona Radiocarbon Laboratory.
} 
cessed at the UCLA laboratory (Haynes 1967: Table 6). This arrangement as well as a portion of the funding for excavations undertaken at Tule Springs was made possible because of the specific interest of Willard Libby in this project (Shutler 1967). The result of the Tule Springs excavations was to remove this site from the list of New World Pleistocene period archaeological sites with suggested ages in excess of that assigned to the Clovis period.

A problem similar to that encountered at Tule Springs was illustrated with the ${ }^{14} \mathrm{C}$ dating of "charcoal" materials from the site of Lewisville in Texas. The apparent charcoal had been recovered in the early 1950s from a series of hearth-like features containing extinct fauna that included mammoth and a Clovis type point (Crook and Harris 1958). Two infinite ${ }^{14} \mathrm{C}$ values were obtained on charcoal samples from the site, 1 sample being designated as coming from "hearth No. 8." The values were cited as >37,000 BP [O-235] and >37,000 BP [O-248] (Brannon et al. 1957). It was initially suggested that the charcoal derived from packrat middens (Heizer and Brooks 1965). However, renewed excavations in the late 1970s determined that portions of the supposed charcoal used for the ${ }^{14} \mathrm{C}$ determinations was actually lignite, a form of coal (Stanford 1982).

Studies associated with the Tule Springs, Old Crow, and several other sites illustrate the continuing efforts to bring evidence to bear that would support the validity of the view that human populations occupied the Western Hemisphere prior to the appearance of Clovis hunters and gatherers. In the 19th century and up until the middle of the 20th century, there had been a number of efforts to provide support of the view that the New World had been occupied by human populations nearly as early as in Europe or Asia. An early example of such efforts is exemplified by the decades-long support by otherwise reputable scholars of the validity of the dating to the Pliocene of a human skull allegedly "discovered" in 1854 in a deep mine shaft in Calaveras County, California. Widely known by members of the local community to have been a hoax perpetrated by a group of local miners, the purported "Tertiary age" Calaveras Skull continued to be advanced as legitimate evidence in a number of scholarly articles in French, German, as well as English until well into the 20th century. In this regard, the Calaveras skull may be regarded as the North American equivalent of the English Piltdown hoax. It had generally been totally discounted by most archaeologists by not later than the early 1950s and thus a ${ }^{14} \mathrm{C}$ determination of $740 \pm 210 \mathrm{BP}$ (UCR-2161B/AA-1879) on an organic fraction of the Calaveras Skull was, in a sense, anticlimactic (Taylor et al. 1992). However, this measurement put an absolute fini to a much too long debated subject.

One of the last reasonably serious scholarly attempts in the later part of the 20th century to provide evidence for the presence of human populations in the New World significantly earlier than the terminal Pleistocene was aggressively advanced by an unlikely advocate, the African prehistorian L S B Leakey [1903-1972] at the Calico site located in the Manix Lake Basin of the western Mojave Desert of southern California (Leakey et al. 1968). Leakey advanced the view that there was sufficient evidence from uranium-series measurements directly on fractured pieces of chert identified by him as artifacts, and on sediments containing chipped lithics that he viewed as the product of human agency, to demonstrate to his satisfaction that these artifacts derived from sediments that were dated as slightly older than 200,000 yr (Taylor 1994b). On this basis, and on the basis of the report of a purported "hearth" in sediments of comparable age, he insisted that there was "no doubt, whatsoever" that there had been established "man-made artifacts in a deposit much older than anything previously found and established in the New World" (L S B Leakey in Schuiling 1972:75). Many of his colleagues, including his wife, Mary Leakey, viewed his advocacy of Calico as a mid-Pleistocene New World site as "catastrophic to his professional career" since to many it had become apparent that he "had lost his capacity to think scientifically" (Leakey 1984:142-3). ${ }^{11}$ 
During the visits of Louis Leakey to southern California to raise funds to support his East African studies and to visit Calico, Libby and Leakey became acquainted. Libby asked his colleague, Rainer Berger [1930-2003], who then directed the UCLA Radiocarbon Laboratory, to become active in scientific studies on materials from the Calico site and other sites and human skeletal samples that might demonstrate a great antiquity for human populations in the New World (Berger R, personal communication, 2001).

Ordinarily, ${ }^{14} \mathrm{C}$ dating would not have been considered relevant in attempts to date materials from the expected time period. However, reflecting, at this time, the high-profile status that Leakey wished to project onto the site and his relationship with Libby, not only uranium-series but ${ }^{14} \mathrm{C}$ measurements on carbonate deposits deposited on stones from the level "which contained most of the suspected artifacts ..." were undertaken by Berger. A carbonate sample exhibited an infinite ${ }^{14} \mathrm{C}$ age of >40,000 BP. Correcting for what was assumed to be the maximum reservoir effect for carbonates in that environment, the reported infinite age was reduced to $>34,000 \mathrm{BP}$ (Berger 1972). Subsequent detailed examinations of the lithic assemblage from Calico called into serious question the anthropogenic origins of the subsurface flaked lithics and failed to confirm that a circular cluster of clasts were, in fact, a "hearth." These studies tended to render the age estimates of the sediments moot.

The characterization of lithics recovered from subsurface contexts at Calico as artifacts was questioned by several experienced investigators (e.g. Haynes 1973) and outright rejected by others as the result of a detailed comparative study of the alleged artifacts and lithics known to be geofacts (e.g. Payen 1982). Thermoremnant magnetization measurements coordinated by Berger with the Czechoslovakian geophysicist Václav Bucha were reported to support the conclusion that the lithics associated with the purported Calico hearth had been subjected to a heating event (Berger R, personal communication, 2001). However, later extended studies of thermoluminescence and electron-spin resonance properties of the chert clasts that were viewed as defining the outline of the Calico "hearth" concluded that no heating event could be demonstrated to have occurred in the vicinity of these rocks for at least 400,000 yr and, thus, "the result of the present study would seem to preclude the possibility fire burned within the feature" (Bischoff et al. 1984:773).

What some have labeled the terminal Pleistocene "Clovis boundary" has been continuously assaulted by a minority of New World archaeologists over several generations. However, of the more than 100 sites in North America which, since the 1930s, had reportedly contained evidence of a pre-Clovis occupation, only a relatively small number currently remain under active consideration with a tendency for new sites to be constantly added by advocates and most then disappearing from active lists of purported pre-Clovis sites within a decade or less. In almost every case of the remaining alleged New World pre-Clovis sites (e.g. Payen 1982; Meltzer 1989; Lynch 1990; Meltzer et al. 1994; Collins et al. 2008), either the cultural nature of the material or the adequacy of the chronometric data associated with the remains-or both—have been questioned. In most cases, ${ }^{14} \mathrm{C}$ age determinations have been and continue to be the crucial arbiter and "gold standard" used in an attempt to document the chronometric age of a given feature or stratigraphic level at a given site locus purported to represent a pre-Clovis human occupation (Haynes 2002).

\footnotetext{
${ }^{11}$ As noted by Haynes (1973:307), the age of the purported artifacts from the Calico site would mean that a "pre-Neanderthaloid" or perhaps, as noted by others, even Homo erectus had been present in the New World during the Middle Pleistocene. It might be mentioned that, as far as this writer is aware, Calico is the only "Early Man" site in North America with its own corporate support group, Web site, and interstate highway information sign. The support group exists as a California nonprofit corporation, the Friends of the Calico Early Man Site, Inc. Its membership is primarily volunteers and avocationalists who conduct guided tours and interpretive activities at the site. Currently (2009), the Web site (www.calicodig.org) continues to be dedicated to advancing the view that Calico is an authentic Middle Pleistocene or, quoting the Web site language, a "New World Paleolithic" archaeological site.
} 
Now essentially a historical footnote in the history of New World archaeological studies were a number of ${ }^{14} \mathrm{C}$ age determinations obtained in the early 1970s on human skeletal materials and the initial results of the application of 2 other dating methods-amino acid racemization (AAR) and uranium series (U-series) - to human skeletal samples that appeared to support a pre-Clovis occupation of the New World. In addition to the ${ }^{14} \mathrm{C}$-based ages on the Los Angeles (Baldwin Hills) [>23,000 BP, UCLA-1430] and Laguna [17,150 \pm 1470 BP (skull), UCLA-1233A and >14,800 BP, UCLA-1233B (long bone)] human skeletons (Berger et al. 1971; Berger 1992), AAR-based age estimates assigned ages of 70,000 yr to the Sunnyvale (northern California) skeleton, >50,000 to the Haverty or Angeles Mesa skeleton (southern California), 48,000 yr to the Del Mar skeleton (southern California) and, apparently confirming an earlier ${ }^{14} \mathrm{C}$ value, $23,000 \mathrm{yr}$ for the Yuha skeleton (southeastern California), although U-series-based determinations indicated an age of about 19,000 yr (Bada et al. 1974; Bada and Helfman 1975; Bischoff et al. 1976; Bischoff and Childers 1979).

The advent of accelerator mass spectrometry (AMS)-based ${ }^{14} \mathrm{C}$ technology made practical a reevaluation of the age estimates obtained on these and other human skeletons due to the ability to measure routinely samples containing a milligram of carbon and, with additional technical efforts, as low as 20 micrograms of carbon (Kirner et al. 1997; Santos et al. 2007). Because of technical advances over several decades, a number of investigators have examined a range of specific molecular fractions isolated from bone that now could be effectively measured (e.g. Stafford et al. 1982, 1990, 1991; Brown et al. 1988; Hedges and Law 1989; Hedges and Van Klinken 1992; Taylor 1994a, 1997; Bronk Ramsey et al. 2004; Higham et al. 2006).

Direct ${ }^{14} \mathrm{C}$ dating or redating by several groups of investigators of specific molecular fractions of bone samples on which previous Pleistocene age ${ }^{14} \mathrm{C}$ values and/or AAR- and U-series-based age estimates had been obtained was undertaken. In each case, the redating determined that all of these human skeletal samples previously assigned Pleistocene ages were, in fact, of Holocene age. For example, the 48,000-yr AAR-deduced age of Del Mar was determined on XAD-purified collagen fractions to range from $5380 \pm 390 \mathrm{BP}(\mathrm{AA}-2666)$ to $4830 \pm 200 \mathrm{BP}(\mathrm{AA}-2665)$, while the AARdeduced 70,000-yr Sunnyvale skeleton was assigned ages ranging from $6300 \pm 400 \mathrm{BP}$ [OxA-187] to $3600 \pm 600 \mathrm{BP}$ [UCR-1437A/AA-50] (Taylor et al. 1985; Stafford 1994). The range in ${ }^{14} \mathrm{C}$ values obtained on both the Del Mar and Sunnyvale bones may, in part, reflect variability in the degree of collagen preservation of the these skeletons (Taylor et al. 1983, 1985; Ennis et al. 1986). Unfortunately, it is still not clear why the initial ${ }^{14} \mathrm{C}$ dates obtained on the Baldwin Hills and Laguna skeletons were anomalous.

Table 1 summarizes ${ }^{14} \mathrm{C}$ age determinations obtained on New World human skeletal samples in excess of 10,000 BP. For North America, currently the oldest, directly ${ }^{14} \mathrm{C}$-dated New World Homo sapiens of which the author is aware is 11,670 $\pm 60 \mathrm{BP}$ (UCR-4000A/CAMS-87301) on a skeleton designated as Naharon I or Eva ("Eve") by Mexican authorities. This determination was obtained on a total amino acid fraction of a human femur recovered from within what is now a submerged cave complex associated with Cenote Naharon, Quintana Roo, Mexico (Taylor 2006). ${ }^{12}$ Unfortunately, an

\footnotetext{
${ }^{12}$ As reported in the National Geographic News (September 3, 2008), the skeleton, which has been designated as Naharon I (since there are other human skeletons present in the cave) and given the popular name Eva de Naharon (Eve of Naharon) by Mexican authorities, was recovered by a group led by Arturo Gonzalez, director of the Desert Museum in Saltillo, Mexico. Nahron I was determined to be female based on the angle of the great sacro-sciatic notch. The age of the individual at the time of death is estimated to be $25-30 \mathrm{yr}$ old (Gonzalez A, personal communication, 2006). As far as this writer is aware, as of this date (2009), no scientific report on the skeletal materials has appeared. Cenote Naharon is one of a number of now flooded cave systems in the Yucatan Peninsula of Mexico, which had been dry before the relatively rapid rise of sea level during the terminal Pleistocene and early Holocene.
} 
examination of the biochemical status of the bone used for the ${ }^{14} \mathrm{C}$ measurement determined that the residual organic carbon content contained less than $0.1 \%$ of that typically found in modern bone and the amino acids isolated from the constituent organics did not exhibit a collagen-like profile. In addition, a ${ }^{14} \mathrm{C}$ measurement obtained on charcoal fragments recovered from sediments from which the bone was recovered yielded a value of $9450 \pm 40$ BP (UCR-4005/CAMS-88589). Based on the data currently available, the indicated ${ }^{14} \mathrm{C}$ age obtained directly on the skeleton should be regarded as problematical and, at best, a preliminary estimate awaiting the presentation of additional data hopefully to be obtained on human skeletal samples from this site with much better protein preservation.

Table $1{ }^{14} \mathrm{C}$-dated New World human skeletal samples $>10,000 \mathrm{BP}$.

\begin{tabular}{|c|c|c|}
\hline Site & Sample/Fraction & ${ }^{14} \mathrm{C}$ age $(\mathrm{BP})$ \\
\hline $\begin{array}{l}\text { Lapa Mortuaria Cave, Brazil } \\
\text { ("Confins Man") }\end{array}$ & acid-insoluble $(\mathrm{NaOH} \text { treated })^{\mathrm{a}}$ & $11,990 \pm 50\left(\right.$ Beta-174680) ${ }^{b}$ \\
\hline Naharon I, Mexico & total amino acids ${ }^{\mathrm{c}}$ & $\begin{aligned} 11,670 \pm 60 & (\mathrm{UCR}-4000 \mathrm{~A} / \\
& \text { CAMS-873010) }\end{aligned}$ \\
\hline $\begin{array}{l}\text { Arlington Springs, Santa } \\
\text { Rosa Island, California }\end{array}$ & XAD-purified gelatin & $10,960 \pm 80 \quad(\text { CAMS-16810 })^{\mathrm{e}, \mathrm{f}}$ \\
\hline Peñon III, Mexico & gelatinization and ultrafiltration & $10,755 \pm 75 \quad(\mathrm{OxA}-10112)^{\mathrm{g}}$ \\
\hline \multirow[t]{11}{*}{ Anzick, Montana } & XAD-purified gelatin & $11,550 \pm 60 \quad(\text { CAMS-35912 })^{\mathrm{f}}$ \\
\hline & glycine & $10,940 \pm 90 \quad(\text { AA } 2981)^{\mathrm{h}}$ \\
\hline & glutamic acid & $10,820 \pm 100(\text { AA } 2979)^{h}$ \\
\hline & hydroxyproline & $10,710 \pm 100(\text { AA } 2980)^{h}$ \\
\hline & XAD-KOH gelatin & $10,705 \pm 35 \quad(\mathrm{CAMS}-80538)^{\mathrm{f}}$ \\
\hline & gelatin & $10,610 \pm 30 \quad(\text { CAMS-80537 })^{\mathrm{f}}$ \\
\hline & total acid-insoluble organics & $10,580 \pm 35 \quad(\mathrm{CAMS}-80535)^{\mathrm{f}}$ \\
\hline & $\mathrm{KOH}$ extracted organics & $10,525 \pm 35 \quad(\text { CAMS-80536 })^{\mathrm{f}}$ \\
\hline & gelatin (untreated) & $10,500 \pm 400(\mathrm{AA} 313 \mathrm{~B})^{\mathrm{h}}$ \\
\hline & alanine & $10,370 \pm 130(\text { AA } 2982)^{h}$ \\
\hline & aspartic acid & $10,240 \pm 120(\text { AA } 2978)^{\mathrm{h}}$ \\
\hline Buhl, Idaho & total acid-insoluble organics & $\begin{array}{r}10,675 \pm 95 \quad \text { (BETA 43055/ } \\
\text { ETH 7729) }\end{array}$ \\
\hline Mostin, California & total acid-insoluble organics & $10,470 \pm 490\left(\text { UCLA }^{2171}\right)^{\mathrm{j}}$ \\
\hline Arroyo Frias, Argentina & gelatin $^{\mathrm{k}}$ & $\begin{aligned} 10,300 \pm 60 & (\text { NSRL-1893/ } \\
& \text { CAMS-16598) })^{1}\end{aligned}$ \\
\hline Tlapacoya I, Mexico & gelatinization and ultrafiltration & $10,200 \pm 65 \quad(O x A-10225)^{g}$ \\
\hline
\end{tabular}

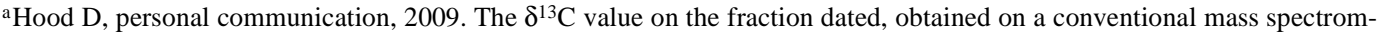
eter, is $-33.4 \%$.

${ }^{b}$ Neves and Hubbe 2005: Table 2 (Supporting Information). The accuracy of this ${ }^{14} \mathrm{C}$ determination is problematical. See text in South America section for additional comments.

${ }^{\mathrm{c}}$ The cited ${ }^{14} \mathrm{C}$ determination was measured on a total amino acid fraction of a femur with a residual carbon content of $<0.1 \%$ of that typically found in modern bone. In addition, the amino acid composition of the sample did not exhibit a collagenlike profile. The accuracy of this ${ }^{14} \mathrm{C}$ value is problematical. See text for additional comments.

d Taylor 2006.

e Johnson et al. 2000.

${ }^{\mathrm{f}}$ Waters and Stafford 2007.

g Gonzalez et al. 2003.

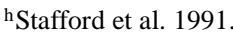

${ }^{\mathrm{i}}$ Green et al. 1998.

${ }^{\mathrm{j}}$ Kaufman 1980.

${ }^{\mathrm{k} S t a f f o r d ~ T W, ~ p e r s o n a l ~ c o m m u n i c a t i o n, ~} 2008$.

${ }^{1}$ Hicks A, personal communication, 1995. 
Purported pre-Clovis sites that continue to be seriously considered by some New World archaeologists have associated with them extensive suites of ${ }^{14} \mathrm{C}$ determinations. In North America, the lowest levels at the Meadowcroft Rockshelter in Pennsylvania, a deeply stratified site excavated in the mid1970s documented by $52{ }^{14} \mathrm{C}$ determinations, has been strongly advanced by its supporters as providing the best documented evidence of North American pre-Clovis occupation. Excavators initially pointed to a ${ }^{14} \mathrm{C}$ value at about $17,000 \mathrm{BP}$ obtained on what was described as a carbonized fragment of cut bark-like material in the lowest cultural unit (Adovasio et al. 1978). By the late 1990s, "applying the most conservative interpretation of the $\left[{ }^{14} \mathrm{C}\right]$ data," support for human occupation at Meadowcroft not later than about 14,000 BP was posited by the original excavator (Adovasio et al. 1998). In 2005, he stated that "[a]pplying the most conservative interpretation ... the minimum age of the presence of human population [at Meadowcroft] is on the order of 10,600-12,000 [BP] . . If the six deepest dates unequivocally associated with cultural materials are averaged ... then humans were definitely present at this site ... sometime between 13,955 and 14,555 [BP]" (Adovasio and Pedler 2005: 26). A vigorous debate has been carried on for almost 3 decades (Dincauze 1981) that, on one hand, raised questions about the potential contamination of samples since a coal-like deposit (vitrinite) and soluble organic carbon ("mung") are exposed in or adjacent to the rock shelter (Haynes 1980, 1991b, 2005; Mead 1980; Tankersley and Munson 1992) and, on the other hand, a vigorous denial that any contamination has ever been identified in any Meadowcroft sample (Adovasio et al. 1980, 1992, 1998; Goldberg and Arkin 1999; Adovasio and Pedler 2005).

Pendejo Cave, New Mexico, with an extensive suite of ${ }^{14} \mathrm{C}$ values documenting more than 55,000 yr of stratified sediments, has been also advanced by its excavators as a site where pre-Clovis occupation has been demonstrated (Chrisman et al. 1996; MacNeish and Libby 2003). This view is based, in part, on human skin imprints on clay from different sediment units ranging in age, based on associated charcoal, from 12,000 to $>35,000 \mathrm{BP}$ and the occurrence of a purported human hair sample directly ${ }^{14} \mathrm{C}$ dated at about $12,000 \mathrm{BP}$. Other investigators have raised a number of questions concerning the relationship of the imprints to the dated sediments and the attribution of the hair as human (e.g. Taylor et al. 1995).

Bonnichsen and Lepper (2005:12) list 28 North American archaeological localities where it is insisted there exist "pre-11,600 [BP] radiocarbon ages, stratigraphy, and associated archaeological remains." There are also, according to these authors, "at least an additional 20 pre-Clovis sites reported from Mexico and South America." Collins et al. (2008) list 15 New World sites where it is alleged that "the aggregate evidence [is] . . robust and undeniable, leading to the conclusion that the Americas were certainly occupied during the interval of $[\sim 13,000$ to $11,600 \mathrm{BP}]$." It might be instructive to compare the current published lists of suggested pre-Clovis sites with those being advanced in about 2020 , i.e. in about $10 \mathrm{yr}$, to ascertain if, after a decade of further study, the same sites continue to be under serious consideration as pre-Clovis. Based on previous experience, it is predicted that less than half of these sites will still be considered by the professional archaeological community as well-documented pre-Clovis localities.

Based on assumptions concerning the number of haplotypes and rates of change in components of the human mitochondrial DNA (mtDNA) genome, several groups of investigators have published suggestions that human populations must have entered the New World sometimes between 15,000 and 40,000 yr ago (e.g. Bonatto and Salzano 1997; Schurr 2004, 2008). A study of DNA from a ${ }^{14} \mathrm{C}-$ dated 9200 BP human skeleton recovered from On Your Knees Cave, Prince of Wales Island, Alaska (Dixon et al. 1997; Dixon 1999) provided data that have raised questions about previous assumptions concerning the genetic composition of the founder populations in the New World. If the original assumptions turn out to have been incorrect, this would indicate that previous temporal infer- 
ences about the arrival times of these founder populations may have been significantly inflated (Kemp et al. 2007).

${ }^{14} \mathrm{C}$ data obtained from several South American sites have also been cited as evidence of Pleistocene occupation of the Western Hemisphere. Dates from one of these sites, Monte Verde, Chile, has reignited long-standing arguments about the specific routes taken by the earliest migrating human populations as they moved into the New World. A discussion of ${ }^{14} \mathrm{C}$ data from Paleoamerican sites located in South America will be considered in the section of this paper dealing with that region.

\section{EASTERN NORTH AMERICA}

James Griffin [1905-1997], the archaeologist who had developed the first major pre- ${ }^{14} \mathrm{C}$ synthesis of eastern US prehistory (Griffin 1946 [actually written 1937]), was directly involved as a central figure in the introduction and articulation of ${ }^{14} \mathrm{C}$ data into the existing matrix of North American archaeological sites with particular focus on eastern North American (Griffin 1952, 1965, 1967; Stoltman 1978). In the pre- ${ }^{14} \mathrm{C}$ era, Griffin had focused his attention on the development of ceramic seriation as a means of providing relative chronologies particularly for the eastern and southeastern portions of the United States. When ${ }^{14} \mathrm{C}$ dating was introduced, Griffin was largely responsible for the initiative that resulted in the development of the University of Michigan ${ }^{14} \mathrm{C}$ laboratory, one of the pioneering ${ }^{14} \mathrm{C}$ facilities in the United States, which, throughout its more than 20 -yr history (1950-72), focused its attention on archaeological samples. In the early years of ${ }^{14} \mathrm{C}$ studies, in at least 2 other instances at United States universities-specifically, the Universities of Arizona and Pennsylvania—archaeologists played important roles in establishing ${ }^{14} \mathrm{C}$ laboratories.

Just as ${ }^{14} \mathrm{C}$ dating was being introduced, Griffin (1952), together with Philip Phillips and James Ford, had undertaken a major review of the chronology for the ceramic periods of the Lower Mississippi Valley. Being aware of the advent of the ${ }^{14} \mathrm{C}$ dating method, the comment was made that "this may be our last chance for old-fashioned, uncontrolled guessing" (Phillips et al. 1951:455). While their analysis pushed back the Mississippian and early ceramic complexes of the region to close to the ages indicated by the first set of ${ }^{14} \mathrm{C}$ values for the region, Griffin (1978:55) would later note that ${ }^{14} \mathrm{C}$ values "altered many of the earlier interpretations of the temporal position of a large number of the cultural complexes recognized by archaeologists. Probably the most important changes have been within the time period attributed to the Archaic cultures, but all other periods have also been affected by the more accurate temporal assessments provided by radiocarbon." One of the most surprising results of the initial ${ }^{14} \mathrm{C}$ values was the age assigned to the fiber-tempered pottery in southeastern United States and in northeastern Florida. The earliest pottery appears about $4500 \mathrm{BP}$ in Georgia and about $4000 \mathrm{BP}$ in Florida. ${ }^{14} \mathrm{C}$ dating contributed significantly to eliminate the possibility of an Eurasiatic origin for Eastern Woodland pottery (Griffin 1968).

Much interest and initial controversy surrounded the dates associated with 2 complexes associated with burial mounds in the Ohio Valley and adjacent areas. The temporal relationship of Adena and Hopewell and how ${ }^{14} \mathrm{C}$ data were to be interpreted in attempting to resolve their chronological relationship occupied the attention of archaeologists in the region for several decades. As was the case in several other regions, e.g. the set of ${ }^{14} \mathrm{C}$ dates dealing with Maya long-count calendar, initial age determinations prompted much consternation as the temporal priority of Adena was called into question. It took more than a decade for the difficulties to be at least partly resolved with the recognition of the lack of association of the dated samples with their alleged archaeological contexts, distinctions between burial and village manifestations, and the temporal overlap between Adena and Hopewell in some regions. 
The advent of agriculture in the eastern United States had been an important regional horizon marker since the absence or presence of agriculture had been a principal feature that initially served to differentiate the Archaic from the later Woodland and Mississippian periods. There had been a tendency for some to claim agriculture as an independent invention in the region, but none of these suggestions could stand as more and more ${ }^{14} \mathrm{C}$ values modified views as to the "first" occurrence of different cultigens in the region. In the 1980 s, AMS-based ${ }^{14} \mathrm{C}$ values on carbonized fragments of squash (Cucurbita sp.) confirmed its occurrence in Archaic period deposits in Illinois at about 7000 BP. By contrast, AMS analysis of fragmentary remains of maize (Zea mays) previously dated at about $2000{ }^{14} \mathrm{C}$ yr on the basis of associated organics determined that the actual age of the maize itself was about $1500 \mathrm{BP}$ at 1 site. In 1 case, the maize fragments were determined to be modern contamination (Conrad et al. 1984). However, later studies, also using AMS technology to obtain direct dates on maize, determined that it was present in the Middle Woodland period about $2000 \mathrm{BP}$ in the upper Mississippi River valley (Riley et al. 1994), but may not have reached New England until as late as AD 1250-1450 (Little 2002).

AMS-based ${ }^{14} \mathrm{C}$ determinations were also used to document conclusively the indigenous occurrence of a North American plant thought by some to have been introduced at the time of European contact. Individual seeds of Corispermum L. (common name, bugseed) were analyzed to eliminate the problems of stratigraphic mixing and late Pleistocene/early Holocene ages were obtained on 4 specimens (Betancourt et al. 1984). Likewise, AMS-based analysis directly on samples of common beans (Phaseolus vulgaris) from sites in the northeastern United States determined their occurrence in the region not earlier than about $650 \mathrm{BP}$ (Hart and Scarry 1999) in contrast to earlier ${ }^{14} \mathrm{C}$ values on purportedly associated charcoal (Ritchie 1969). AMS technology has also made possible ${ }^{14} \mathrm{C}$ measurements of trace concentrations of charcoal used as a pigment to date the time frame of motifs used on pictographs such as found in Picture Cave, Missouri (Diaz-Granádos et al. 2001), although cautionary concerns have been expressed about problems introduced as the result of the possibility of the use of "old wood/charcoal" in some contexts (Armitage et al. 2001)

\section{WESTERN NORTH AMERICA}

Like most areas of the New World, chronological understandings concerning the prehistoric cultures of western North America can, with justification, be divided into "pre- ${ }^{14} \mathrm{C}$ " and " ${ }^{14} \mathrm{C}$ " eras. Although excavations in Lovelock Cave, Nevada, benefited from the introduction of statigraphic strategies introduced by N C Nelson, until the late 1940s, with few exceptions, the majority of the archaeology conducted by those with various levels of training and experience focused on artifact collecting. Chronological relationships were initially structured by comparing Great Basin materials with those from other regions, most notably, the Southwest (Heizer and Hester 1978). However, a focal feature of traditional chronology building in the Great Basin has been the use of projectile points as time markers and much interest was focused on the relationship of various dated series, primarily recovered from caves and rock shelters, with the various regional projectile point series (Hester 1973). This is of particular importance in a region where the vast majority of investigated sites represent surface features and the projectile points themselves are the sole means of establishing temporal control.

An important theme in Great Basin archaeology has been various views concerning purported lengthy abandonment(s) of parts of the region. Region-wide abandonment was first postulated to coincide with the Altithermal, a period of decreased effective moisture dated to between about 7000 and 4500 BP (Baumhoff and Heizer 1965). Other interpreters suggested that entire eastern Great Basin was abandoned by human populations between about 3200 and 1500 BP (Madsen and Berry 
1975). A significant element of these arguments involved the interpretations ${ }^{2}{ }^{14} \mathrm{C}$ dates and associated cultural materials in a series of caves and rock shelter contexts to infer changes in human population densities over time in the region. A critique of this view notes that the use of ${ }^{14} \mathrm{C}$ values for such purpose is usually very problematical in part due to the differential availability of datable materials from closely-spaced levels in sites and the relatively high cost of obtaining sufficient ${ }^{14} \mathrm{C}$ analyses to permit the secure documentation of any purported hiatus (Aikens 1976).

In some versions of earlier discussions concerning the abandonment of portions of the Great Basin, this argument was associated with defining the period of the introduction of the bow and arrow to the region. Clarification of this issue is associated with obtaining ${ }^{14} \mathrm{C}$ determinations on materials from stratified deposits containing both dart points and arrow points. For example, a suite of ${ }^{14} \mathrm{C}$ determinations from the Rose Springs site in the western Great Basin allows the dating of the earliest occurrence of arrow points at this site at about $1600 \mathrm{BP}$. This result is consistent with the time range for the appearance of bow and arrow technology in other regions of western North America (Yohe 1992).

Western North American archaeology has yielded a number of case studies of the effect of the loss of stratigraphic association for samples in cave and rock shelters that can occur both during succeeding occupations as well as after the abandonment of sites. An example of such a problem is illustrated by the ${ }^{14} \mathrm{C}$ analysis of materials from Gypsum Cave, Nevada. Atlatl shaft fragments and dung from an extinct giant ground sloth were found in apparent association. An early ${ }^{14} \mathrm{C}$ date obtained by the Chicago laboratory on the dung determined its age to be approximately 10,000 BP (Libby 1952: 85 ) and this value was used to infer an age for the atlatl fragments. More than a decade later, a ${ }^{14} \mathrm{C}$ analysis directly obtained on one of the atlatl shafts determined that their age to be about $3000 \mathrm{BP}$ (Berger and Libby 1967).

The same difficulty was encountered in determining the age of fragments of atlatl dart shafts that had been recovered from Potter Creek Cave in northern California in the early part of this century. The dart shaft fragments were originally thought to have been contemporaneous with extinct Pleistocene fauna found in the cave. However, ${ }^{14} \mathrm{C}$ ages obtained directly on the atlatl shaft fragments later determined that there were not older than about 2000 BP. This indicated at least a 6000-8000 yr temporal hiatus between the extinct fauna and the cultural materials in this cave (Taylor 1975; Payen and Taylor 1977). By contrast, an artifact in the form of woven rope sandals recovered from Fort Rock Cave in Oregon was demonstrated to be of early Holocene age with a ${ }^{14} \mathrm{C}$ age directly obtained on the sandal material itself of $9053 \pm 350$ BP [C-428] (Libby 1952:87).

In northwestern North America, ${ }^{14} \mathrm{C}$ values have provided the principal chronological controls for 2 major late Pleistocene and early Holocene chronostratigraphic markers used by archaeologists and other Quaternary scientists. The first marker is a series of tephra beds produced as the result of a series of eruptions at Glacier Peak, Washington, which have been identified in more than 150 sites in the northwestern part of the US, southern parts of Alberta, and southwestern Saskatchewan in Canada (Porter 1978). Several Clovis period sites, e.g. East Wenatchee, Washington (Mehringer and Foit 1990), have been directly associated with the G and B Glacier Peak tephra beds. A group of 15 ${ }^{14} \mathrm{C}$ values obtained on organic samples having clear stratigraphic relationship to the geochemically well characterized $\mathrm{G}$ and B beds Glacier Peak tephra samples analyzed within a Bayesian statistical framework produced a value of $11,600 \pm 50 \mathrm{BP}$ as the most likely age of these beds (Kuehn et al. 2009).

A second chronostratigraphic marker for this region was produced by a violent eruption of Mount Mazama in the southern Oregon Cascade range. Probably the largest Holocene eruption in North 
America, this event distributed volcanic ash from central Nevada to British Columbia (Bacon 1983). The event has been characterized by mineralogical analysis of tephra sediments in many archaeological sites, geological contexts, and lake sediment cores throughout the region. A review of the ${ }^{14} \mathrm{C}$ determinations associated with the eruption has identified 65 values obtained by 16 laboratories over the last 5 decades (Hallet et al. 1997: Table 1). The first ${ }^{14} \mathrm{C}$ determination was obtained in the early 1950s by Libby's Chicago laboratory and was cited as $6453 \pm 250$ BP [C-247) representing an average to four separate measurements (Libby 1952:86). Critical reviews of the entire corpus of dates place the eruption event within a century of $6800 \mathrm{BP}$ with one investigator calculating $6845 \pm$ $50 \mathrm{BP}$ (Bacon 1983) and a second $6730 \pm 40 \mathrm{BP}$ (Hallet et al. 1997). The slightly younger value has reportedly been supported by data from the Greenland GISP2 ice core on the basis of a correlation with a $\mathrm{SO}_{4}$ peak associated with the explosive event (Southon and Brown 1995; Zdanowicz et al. 1999:623).

The usefulness of this eruption event as a regional time marker is illustrated in the determination that a human skeleton recovered near Kennewick, Washington, in the mid-1990s was associated with Mount Mazama sediments. Both the ${ }^{14} \mathrm{C}$ data and the subsequently obtained environmental contextual data and the approach taken to the study of the Kennewick skeleton are used in this discussion as a case study in the application of ${ }^{14} \mathrm{C}$ data in archaeology in the context of its geological placement in a sedimentary record as well as issues involving the validity of ${ }^{14} \mathrm{C}$ values on bone samples.

\section{NORTH AMERICAN ${ }^{14} \mathrm{C}$ DATING CASE STUDY: THE KENNEWICK SKELETON}

An informative illustration of the influence not only on archaeological scholarship but also on public policy issues dealing with the legal rights of Native Americans in the United States to claim ownership of ancient skeletal materials began with a single ${ }^{14} \mathrm{C}$ age determination on a human skeletal sample..$^{13}$ In the summer of 1996, first a human skull and then, over a period of several months, disarticulated human bones were recovered from shallow water adjacent to an embankment on the southern shore of a dammed section of the Columbia River at a locality adjacent to Columbia Park within the community of Kennewick, Washington (Nickens 1998; McManamon 1999a; Chatters 2000).

Based primarily on various conventional skeletal morphological criteria, the Kennewick skeleton from the Columbia Park site was initially thought to be that of a historic contact period Euro-American settler. However, the first of $5{ }^{14} \mathrm{C}$ determinations on the Kennewick skeleton yielded a ${ }^{14} \mathrm{C}$ value (UCR-3476/CAMS-29578) of $8410 \pm 60$ BP (Taylor et al. 1998). The presence of an early Holocene human skeleton in North America exhibiting morphological features determined by several physical anthropologists with long experience evaluating North American aboriginal skeletal

\footnotetext{
${ }^{13}$ The Native American Graves Protection and Repatriation Act (NAGPRA), which became federal law in the United States in 1990, mandated a process whereby museums and federal agencies were required to return certain Native American cultural items including human remains to descendants of federally recognized Native American tribes. Following the discovery of the Kennewick skeleton, a local Native American group requested that the skeletal remains be turned over to them for reburial since the locality where the skeleton was recovered belonged to an agency of the federal government, the US Corps of Engineers. The National Park Service, the federal agency given the task of administering NAGPRA, determined that the remains would be given to this Native American group until a lawsuit filed by a group of archaeologists sought to prevent that action (McManamon 1999b). A federal judge determined that the original NAGPRA legislation applied only to situations where direct descent could be demonstrated. In the absence of scientific evidence that a human skeleton at least 8000 yr old represented an ancestor of a specific contemporary federally-recognized Native American tribe, the federal agency was directed to conduct further scientific studies on the materials. Native American groups have sought legislation to amend NAGPRA to have it apply to any skeletal material no matter how old. These efforts have been opposed by a majority of members of the United States professional archaeological community (Downey 1999; Thomas 2000; Chatters 2001).
} 
materials as uncharacteristic of recent Native American populations engendered both widespread popular media and scientific interest (Downey 1999; Thomas 2000; Chatters 2001).

An analysis of skeletal morphometric data determined that these remains represented a single male individual, approximately $175 \mathrm{~cm}\left(5^{\prime} 9^{\prime \prime}\right)$ in stature who had died between 45 and $50 \mathrm{yr}$ of age (Powell and Rose 1999). He had been wounded by a projectile point which became lodged within the right iliac blade of his pelvis. From a taphonomic perspective, the Kennewick remains represent an individual who was most probably intentionally buried rather than left to decompose on the surface. In terms of the number of bone elements recovered, this skeleton currently represents the most complete early Holocene human skeleton currently known from the Western Hemisphere.

Based on measurements of the skull, it was reported that the most similar samples appeared to be those from the south Pacific and Polynesia as well as the Ainu of Japan, a pattern that had emerged from the study of other early Holocene American crania from North and South America. It was concluded that the Kennewick skeleton can be excluded, on the basis of its cranial morphology, from late Holocene American Native American groups (Steele and Powell 1992, 1994; Jantz and Owsley 1997; Powell and Rose 1999).

Extensive geologic and geomorphological studies were undertaken at the Columbia Park site to obtain an estimate of the age of the sediments associated with the skeleton (Wakeley et al. 1998; Huckleberry and Stein 1999). One of the important issues that was addressed was whether the geologic evidence supported the age of the skeleton as determined by the initial ${ }^{14} \mathrm{C}$ age. Directly relevant to that question was the determination that Mt. Mazama tephra was identified in a number of places in the soil sections and in sediments adhering to various Kennewick bones (Huckleberry et al. 1998).

${ }^{14} \mathrm{C}$ values obtained on soil humates extracted from coring exhibited ${ }^{14} \mathrm{C}$ values ranging in age from about 9000 to $15,000 \mathrm{BP}$. The youngest of the soil humate ${ }^{14} \mathrm{C}$ values $(9010 \pm 50 \mathrm{BP}$ [WW-1626/ CAMS-44572]) was derived from the base of a concretion-bearing sediment, which, on the basis of the comparison of organic and carbonate concentrations in the sediment and those adhering to the Kennewick bones, was inferred to be that which originally contained the Kennewick skeleton. The investigators concluded that "if we assume that the Mazama tephra is in situ and that the ${ }^{14} \mathrm{C}$ age [of the associated soil humate sample] is correct, then the geologically correlated age for the skeleton is 6700-9000 BP” (Huckleberry and Stein 1999:22).

A typological assessment based on CT imaging concluded that the projectile point embedded in the pelvis of the skeleton resembled a Cascade Point, a dart point type first characterized by Butler (1961:28-9), who considered it a diagnostic trait of the Cascade phase. This phase was the second earliest of 5 phases originally defined for the Lower Snake River culture sequence of southwestern Washington (Leonhardy and Rice 1970). Cascade phase assemblages are present in sites throughout the Pacific Northwest (Newman 1966; Nelson 1969; Rice 1972). They have often been associated with volcanic ash deposits of the Mt. Mazama eruption, which, as discussed above, critical reviews of the large corpus of ${ }^{14} \mathrm{C}$ values place within a century of 6800 BP. Fagan (1999:5) concluded that the Columbia Park specimen embedded in the Kennewick skeleton more closely resembles points most often immediately post-dating the Mt. Mazama ash. On this basis, in his view, the specimen is thought to represent "a tool made and used during Early Archaic times between 5,000 and 7,000 years ago." Chatters (2000:298) identified serrated edges on the sample and, on this basis, suggested that it should predate the Mazama ashfall and thus date to between 5000 and 8000 BP. 
Table 2 lists ${ }^{14} \mathrm{C}$ determinations obtained directly on 3 different bones of the Kennewick skeleton. Two of the bones had been split into 2 portions and sent to different ${ }^{14} \mathrm{C}$ laboratories. As the result of several decades of research, there is widespread agreement that an important factor in obtaining accurate individual bone ${ }^{14} \mathrm{C}$ values is the degree to which a bone sample had retained significant amounts of its principal protein component, collagen.

Table 2 Kennewick human bone samples: ${ }^{14} \mathrm{C}, \delta^{13} \mathrm{C}$, and geochemical data (adapted from Taylor et al. 2001).

\begin{tabular}{|c|c|c|c|c|c|}
\hline Lab nr & Bone & $\begin{array}{l}\text { Preservation } \\
\text { indices }^{\mathrm{a}}\end{array}$ & Fraction measured & $\begin{array}{l}\delta^{13} \mathrm{C} \\
(\% o)\end{array}$ & $\begin{array}{l}{ }^{14} \mathrm{C} \text { age } \\
\text { (BP) }\end{array}$ \\
\hline $\begin{array}{l}\text { UCR-3476/ } \\
\text { CAMS-29578 }\end{array}$ & 5 & ) & total & -14.9 & $8410 \pm 60$ \\
\hline BETA-133993 ${ }^{b}$ & 1st right metacarpal & $-^{c}$ & $\begin{array}{l}\text { base-treated } \mathrm{HCl}- \\
\text { insoluble }\end{array}$ & -12.6 & 8410 \\
\hline $\begin{array}{l}\text { UCR-3807/ } \\
\text { CAMS-60684 }\end{array}$ & 1 st rigl & $14.3 \%(\mathrm{NC})$ & total amino acids & -10.8 & $8130 \pm 40$ \\
\hline $\begin{array}{l}\text { UCR-3806/ } \\
\text { CAMS-60683 }\end{array}$ & left tibial crest & $2.3 \%(\mathrm{NC})$ & total amino acids & -10.3 & $6940 \pm 30$ \\
\hline AA- $34818^{d}$ & left tibial crest & - $^{\mathrm{e}}$ & gelatin & -21.9 & $5750 \pm 100$ \\
\hline
\end{tabular}

andices of bone preservation expressed as \% of amino acid carbon content of modern bone standard and collagen or noncollagen-like amino acid profile. $\mathrm{C}=$ collagen-like amino acid composition; $\mathrm{NC}=$ non-collagen amino acid composition. ${ }^{\mathrm{b}}$ Reported by D Hood in McManamon (1999b).

'D Hood (Beta Analytic) reports that the "amount of collagen extracted" was $0.3 \%$ of the bone taken, a "value [which] is very low due to the high mineral content of the submitted bone."

${ }^{\mathrm{d}}$ Reported by D Donahue in McManamon (1999b).

${ }^{\mathrm{e}} \mathrm{D}$ Donahue (University of Arizona) in McManamon (1999b) reports that the "carbon yield for this sample was $0.05 \% \ldots$ well below the yield for which we would usually quote a result."

To obtain a quantitative measure of the degree of collagen retention in 3 of the bones studied, 1 laboratory (UCR) determined the amounts of carbon contained in the total amino acid fraction isolated from these bones by ion exchange chromatography as a percentage of that present in modern bone, as well as a profile of the constituent amino acids to identify which bone had retained a collagen-like amino acid profile. The 2 other laboratories that obtained measurements on Kennewick bone reported the "amount of collagen extracted" and "carbon yields" (Table 2, footnotes [c] and [e]). Of the 3 bones dated by the UCR laboratory, only 1 (UCR-3476/CAMS-29578) retained both a significant fraction of its collagen and exhibited a collagen-like amino acid pattern. The range of ${ }^{14} \mathrm{C}$ values obtained on different bones and different parts of the same bone in a single skeleton provide an excellent illustration of the effect of decreasing collagen concentration on the indicated ${ }^{14} \mathrm{C}$-deduced age of that bone. ${ }^{14}$

\footnotetext{
${ }^{14} \mathrm{In}$ addition to the Kennewick bones on which both ${ }^{14} \mathrm{C}$ and $\delta^{13} \mathrm{C}$ values were obtained, the $\delta^{13} \mathrm{C}$ and amino acid compositions of 8 other Kennewick bones were analyzed. The maximum and minimum of the $\delta^{13} \mathrm{C}$ values was $-15.1 \%$ ond $-12.9 \%$, although the $\delta^{13} \mathrm{C}$ values of 6 of the 8 bones were more tightly clustered in the range of -13.2 to $-13.6 \%$. There was significant variability in the degree of retention of various amino acids that served as a proxy for the degree of preservation of the collagen matrix in each bone. As a percentage of that measured in modern bone, the values ranged from $10.1 \%$ to $46.2 \%$. Measurements obtained on the proximal and distal end of the 3rd right metacarpal determined that the percentage retention of the constituent amino acids in this single small Kennewick bone ranged from $10.1 \%$ to $32.6 \%$ (Taylor 2001).
} 
The $\delta^{13} \mathrm{C}$ value exhibited by UCR-3476/CAMS-29578 indicated the presence of a marine signal presumably reflecting a high percentage intake of marine-derived biomass in the diet of Kennewick Man. Salmon was assumed as the dominant fish in the diet based on contact period ethnographic accounts and archaeological data, although steelhead (Oncorhynchus sp.) has also been suggested (Chatters 2000:299). It was assumed that 100\% marine and 100\% terrestrial diets would give rise in a total amino acid fraction $\delta^{13} \mathrm{C}$ values of $-12.8 \%$ and $-19.6 \%$, respectively, following the approach outlined in Chisholm et al. (1982). Given the $\delta^{13} \mathrm{C}$ value of $-14.9 \%$ or UCR-3476/CAMS-29578, a marine dietary protein contribution of $70 \pm 10 \%$ was calculated assuming an uncertainly of $\pm 1 \%$ o in the dietary end points.

Assuming that early Holocene Columbia River salmon accumulated most of their biomass within the Gulf of Alaska in a manner similar to that observed today (Groot and Margolis 1991), a marine offset correction for the Kennewick sample was calculated. ${ }^{14} \mathrm{C}$ ages for early 20th century marine shell from the Gulf of Alaska average 860 BP (Robinson and Thompson 1981), while terrestrial ages were close to $110 \mathrm{yr}$ (Stuiver et al. 1986, 1998). On this basis, the marine reservoir correction for this region was estimated as $750 \mathrm{yr}$.

The spread in marine shell ages from around the Gulf (Robinson and Thompson 1981) and results from archived pre-1950 salmon scales (Brown et al. 1998) suggest that a reasonable estimate for the geographic variability in this correction value is the equivalent of $\pm 60 \mathrm{yr}$. The scatter in paired wood-shell ${ }^{14} \mathrm{C}$ ages from the British Columbia coast (Southon et al. 1990) indicate that early Holocene variations of this correction of up to $\pm 150 \mathrm{yr}$ represents a realistic estimate of variability. Adding these values in quadrature, $\pm 160 \mathrm{yr}$ can be considered as a conservative estimate of the overall uncertainly for the reservoir correction at 7000 to $8000 \mathrm{BP}$ in the Gulf of Alaska. Based on these results and the estimated marine dietary contribution, the corresponding marine reservoir offset for the Kennewick ${ }^{14} \mathrm{C}$ values was calculated as $530 \pm 140 \mathrm{yr}$. On the basis of these considerations, a reservoir-corrected ${ }^{14} \mathrm{C}$ age for the Kennewick skeleton was determined as $7880 \pm 150 \mathrm{BP}$ (UCR-3476/ CAMS-29578).

The Kennewick skeleton is one of a small number of directly ${ }^{14} \mathrm{C}$-dated terminal Pleistocene and early Holocene human skeletons from the New World currently known to date to the early Holocene, i.e. to be older than 7500 BP. However, unlike Kennewick, where almost $90 \%$ of the bones have been recovered, all but 2 of the other late New World Pleistocene/early Holocene skeletons are represented by very fragmentary remains. The Kennewick skeleton represents one of the most completely studied New World prehistoric human skeleton not only from the perspective of its geological and chronological provenience but also its morphological and isotopic status.

\section{SOUTHWESTERN UNITED STATES}

In the early part of the 20th century, the American Southwest became a focal point of New World archaeological studies, in part due to the climate of the region being attractive to archaeologists from northeastern US institutions during the winter months in the Northern Hemisphere. It is important to note that the region enjoyed one of the earliest applications of stratigraphic excavation strategies in the New World combined with typological and seriation approaches to the temporal analysis of ceramics and other artifact types. Several factors contributed to this status, but, of these, probably the most important was that for North America north of Mexico the region enjoyed the most secure prehistoric chronometric framework in the pre- ${ }^{14} \mathrm{C}$ period. This was because of the development of tree-ring dating or dendrochronology in the 1930s and its application to the archaeological record of the region. 
Dendrochronology was developed and applied in the Southwest by an astronomer, Andrew Ellicott Douglass [1867-1962], more than 2 decades prior to the introduction of the ${ }^{14} \mathrm{C}$ method (Nash 2000). Because of the eventual effectiveness of dendrochronological approaches for temporal resolution for approximately the last 2 millennia - the period beginning with Basket Maker II on the Colorado Plateau and Mogollon I for central Arizona and New Mexico- ${ }^{14} \mathrm{C}$ data was not aggressively pursued for Pueblo, Mogollon, and Hohokam sites and materials. However, ${ }^{14} \mathrm{C}$ data were employed in Southwestern subregions where dendrochronology could not be reliably extended-such as the southern Arizona Desert—and for "Archaic cultures" in excess of about 2000 BP (Rohn 1978).

Of early significant interest was the Chicago ${ }^{14} \mathrm{C}$ date of about $5900 \mathrm{BP}$ determined on charcoal from a lower level in Bat Cave, New Mexico, purportedly associated with early forms of domesticated maize (Dick 1965). From the beginning, the results were suspect or, as Frederick Johnson termed it, "tenuous," because of problematic associations (Johnson 1955:154). Since that time, attempts to date the arrival of maize and other cultigens in the Southwest have been controversial (Simmons 1986). The development of AMS ${ }^{14} \mathrm{C}$ technology applied resulted in a set of analyses that have been obtained directly on the cultigens rather than on associated organics. An excellent example of the effects of direct dating of domesticates in contrast to earlier ${ }^{14} \mathrm{C}$ dates on associated organics is available from the experiences at the Fresnal Shelter in southern New Mexico (Tagg 1996). Minnis (1992) and Hard and Roney (1998) assembled the results of such direct dating at sites in Arizona, Utah, New Mexico, and Chihuahua, Mexico. Currently, the earliest reliable evidence for cultigens in this region is about $3000 \mathrm{BP}$ with maize, beans, and 1 species of squash arriving first.

\section{MESOAMERICA}

Mesoamerica was a region in pre-Hispanic times, which, from an archaeological or prehistoric cultural perspective, encompassed the southern two thirds of modern Mexico as well as most of what is now considered Central America. The major archaeological features that initially attracted scholarly and popular attention beginning in the 19th century were extensive ruins of large monumental structures in sites in southern Mesoamerica (e.g. Tikal and Copan), in the Valley of Mexico (e.g. Teotihuacan), and in the Valley of Oaxaca (e.g. Monte Alban). The use of a long-count calendar system and an extensive inscriptional textual corpus is known from both Maya sites and non-Maya sites of southern Veracruz and neighboring Chiapas. In the case of the Maya calendar, the long-count system involved a continuous recording of days from a fixed zero point. Hieroglyphic texts and calendar notations were inscribed on stela and on various architectural elements of buildings within temple complexes including those constructed of wood.

Long-count dates were extensively employed in Maya archaeology to associate ceramic types with architectural phases for the Maya Classic period (Fedick and Taube 1992). A long-standing question was the correlation of the pre-Hispanic lowland Maya long-count calendar with the Western calendar. At the time of the introduction of the ${ }^{14} \mathrm{C}$ method, the majority of Mayan scholars had tentatively accepted, from a lengthy list of correlation formulas, the "GMT" (Goodman-MartinezThompson) correlation as best fitting the available evidence, although a correlation formula devised by $\mathrm{H} \mathrm{J}$ Spinden continued to have adherents. ${ }^{15}$

\footnotetext{
${ }^{15}$ At the present time, the most widely used correlation accepted by most (but not all) Maya scholars is the "Goodman-Martinez-Thompson" (GMT) correlation. The GMT correlation formula places the 0.0.0.0.0 Maya date on August 11, 3114 BCE. This does not mean that this calendar was actually in use in the 3rd millennium BC, but that later Mayan priest-scholars established this date as the starting date for their calendar (Thompson 1971).
} 
The first ${ }^{14} \mathrm{C}$ determination bearing on the Maya correlation problem was obtained by the Lamont Radiocarbon Laboratory, Columbia University, on a sample of wood extracted from a wooden lintel inscribed with a Maya long-count calendar notation from the Classic Maya site of Tikal in Guatemala (Kulp et al. 1951:566). Surprisingly, rather than supporting the GMT correlation, the ${ }^{14} \mathrm{C}$ value on the lintel supported the Spinden correlation scheme, which yielded ages exactly $160 \mathrm{yr}$ earlier than did the GMT formula. A second ${ }^{14} \mathrm{C}$ determination on another inscribed wooden lintel from Tikal bearing the same long-count data as in the first test was undertaken at Chicago by Libby and also supported the Spinden correlation (Libby 1954:740).

These results were criticized on the basis that there were derived from wood samples from existing museum collections whose size had been reduced for transport and thus had lost their outside rings (Satterthwaite and Ralph 1960). The result of these initial results was the first intensive dating program undertaken by a ${ }^{14} \mathrm{C}$ laboratory in conjunction with an major archaeological excavation - in this case at Tikal from 1955-1970 by the University Museum of the University of Pennsylvania. The first topic addressed was the ${ }^{14} \mathrm{C}$ dating of lintels of temple structures on which were inscribed Maya long-count calendar dates. In selecting these samples, there was an explicit recognition of a problem with wood samples containing a number of rings. The issue was first labeled the "post-samplegrowth (or inner wood) error" and then renamed, more appropriately, the "pre-sample growth error" (Ralph 1971:4).

New collections of wood samples with due consideration of the problem of missing rings were obtained during the University of Pennsylvania excavations. In a critical interpretation of the resultant ${ }^{14} \mathrm{C}$ data, involving more than 100 determinations obtained by the University of Pennsylvania ${ }^{14} \mathrm{C}$ facility and later by the UCLA laboratory, the pre-sample growth factor was employed to explain the earlier determinations. By this time, there were the beginnings of an understanding of calibration issues for ${ }^{14} \mathrm{C}$ values. Fortunately, early paired tree-ring $/{ }^{14} \mathrm{C}$ data indicated a close correspondence between ${ }^{14} \mathrm{C}$ and solar time for the temporal period at issue (Satterthwaite and Ralph 1960; Ralph 1965). Most, but not all (e.g. Andrews 1978), Mayanists came to accept the new ${ }^{14} \mathrm{C}$ results as strongly supporting the GMT correlation (Kelley 1983).

In the mid-1960s, the pre-sample growth factor was also invoked to resolve problems of correlating ${ }^{14} \mathrm{C}$ determinations on charcoal with the ceramic chronological sequence for the Classic period usually dated to span from AD 200 to AD 600 at Teotihuacan in central Mexico (Kovar 1966). Since Teotihuacan was the American continent's first fully urban site and, in all likelihood, the capital of a politically and economically powerful Mesoamerican empire, the chronology of its rise, development, and eventual abandonment was of great significance in understanding the evolution of what was probably the largest and most complex state system to emerge in the New World (Cowgill 2008).

Unlike most of the other large-scale, complex societies in other parts of the world, no textual data have come down to modern scholars that would allow the development of a high-resolution historical chronology for the site. In the absence of such data, ${ }^{14} \mathrm{C}$ values, sometimes in combination with other dating strategies such as provided by archaeomagnetic data, are the principal means of deriving a detailed chronology. A detailed review of the existing suite of 30 wood and charcoal ${ }^{14} \mathrm{C}$ values specifically associated with specific construction phases evaluated in terms of the calibration intervals, combined with Bayesian statistical modeling, has yielded a result that the last major construction phase at Teotihuacan ended as much as a century earlier than previously determined (Beramendi-Orosco et al. 2009). 
${ }^{14} \mathrm{C}$ dating has been extensively employed to provide temporal resolution for what some archaeologists considered the "mother culture" (cultura madre) of ancient Mesoamerican civilization, the Olmec, as represented at sites such as La Venta and Tres Zapotes located in the Gulf Coast region of Mexico. Initially, many archaeologists considered these Olmec sites to predate the Classic period in the Yucatan Peninsula. Others viewed the Olmecs as contemporaneous with or even to postdate the Classic Maya. A series of ${ }^{14} \mathrm{C}$ values obtained from La Venta in the late 1950s demonstrated clearly that the Olmecs at this site predated the Maya by many centuries (Drucker et al. 1957:265). A suite of ${ }^{14} \mathrm{C}$ values obtained during studies at the site of San Lorenzo documented an even earlier Olmec phase reaching back to at least 3000 BP (Coe and Diehl 1980:395-6).

The question of the origins of plant domestication in the New World had been long been centered on Mesoamerica in light of the fact that the wild precursors of the major domesticates-and especially maize (Zea mays) - were generally considered to be indigenous to that region. A series of major excavations in a number of caves and rock shelters in Tehuacan Valley in central Mexico in the 1960s, which was specifically directed at elucidating the course of plant domestication in the region, revealed a long stratigraphic record covering most of the Holocene (Byers 1967-1972). Contained in these deposits at various levels were fragments of a number of plant domesticates. A large suite of ${ }^{14} \mathrm{C}$ dates primarily on associated charcoal provided the chronology for development of domesticated species (Johnson and Willis 1970; Johnson and MacNeish 1972). Charcoal ${ }^{14} \mathrm{C}$ values were used to assign age to the individual fragments of early maize as early as $7000 \mathrm{BP}$. Concerns regarding the association of charcoal with the maize fragments were later addressed when AMS-based ${ }^{14} \mathrm{C}$ measurements on the maize specimens themselves determined that there was a considerable range in the ages of the individual specimens with the oldest directly dated cultigen exhibiting an age of about 4700 BP (Long et al. 1989).

\section{SOUTH AMERICA}

The intellectual and institutional histories of archaeological studies in South America are in significant contrast to that of North America but share a number of common features with that of Mesoamerica. With some notable exceptions, as was the case with Mesoamerica, North American and European scholars were the earliest professionals who began archaeological and paleontological studies in most areas of South America. Much initial field work was also undertaken by local naturalists and avocationalists. In addition, as noted by Neves (Neves and Hubbe 2005), for a significant portion of South America now occupied by modern Brazil, the majority of archaeological reports were written in Portuguese and appeared in local publications. However, over the last 4 decades, a number of nationals from a number of countries in the subcontinent have come to assume leading roles in the study of their various prehistoric pasts and have published their studies in publications more accessible to an international scholarly community.

As was the case in North America, the question of the earliest peopling of the South American continent created significant early interest among a number of 19th century American and European naturalists. Now only a historical footnote was the effort in the 1870s of an European-trained Brazilian paleontologist, Florentino Ameghino, the Director of the Natural History Museum of Buenos Aires, to demonstrate that humans had evolved in South America (Nelson 1933:92). One of the best known were the initial reports of the association of human bones, artifacts, and fossilized remains of Pleistocene megafauna from various caves in the region around Lagoa Santa in east central Brazil. The Danish paleontologist Peter Wilhelm Lund [1801-1880], based primarily on his work at Gruta do Sumidouro, argued for the association of human skeletal materials and Pleistocene fauna, a claim later totally rejected by Hrdlička and colleagues at the Smithsonian Institution in the first modern, critical review of the evidence of humans in South America (Hrdlička et al. 1912). 
Excavations carried out at the Lapa Mortuária de Confins, Brazil, in the 1930s recovered a human skeleton ("Confins Man") reportedly excavated from a layer that was overlaid by stalagmite containing mastodon and bone of an extinct species of horse. The similarity in fluorine content of the cranium of "Confins Man" and a bone assumed to be Pleistocene age found in the same level was used to argue for their direct association (Walter et al. 1937). A ${ }^{14} \mathrm{C}$ determination obtained on this skeleton is reported as 11,990 $\pm 50 \mathrm{BP}$ [Beta-174680] (Neves and Hubbe 2005: Table 2 [Supporting Information). An anomalous $\delta^{13} \mathrm{C}$ value obtained on the base-extracted, acid-insoluble fraction used for the ${ }^{14} \mathrm{C}$ measurement may have been a factor that occasioned a puzzling footnote of "Date under confirmation" in the report of the ${ }^{14} \mathrm{C}$ results. In light of the data currently associated with this analysis, the accuracy of the reported ${ }^{14} \mathrm{C}$ value on "Confins Man" should be regarded as questionable and, at best, a preliminary estimate awaiting the presentation of additional data.

A regional study of the archaeology of other caves in the Lagoa Santa region by Hurt (1960) reported that there was no evidence in any of the sites examined by him that demonstrated the contemporary nature of human occupation with Pleistocene fauna. Studies of the sediments in these caves concluded that, over the Holocene, the caves had gone through alternating periods of cool-dry and hot-damp climate, and it was posited that they explained the stalagmite covering bones in many of the caves in the region. These environmental conditions might also explain the similar fluorine contents in the human and assumed Pleistocene age bones.

The first major series of ${ }^{14} \mathrm{C}$ determinations from the Lagoa Santa region was the result of joint Franco-Brazilian efforts at the site of Lapa Vermelha IV. The oldest ${ }^{14} \mathrm{C}$ determination obtained on charcoal with an assumed human skeletal association including the Lapa Vermelha IV hominid ("Luzia") was 11,680 \pm 50 BP [Gif-3728], although a later determination obtained directly on human bone was reported as $9330 \pm 60$ BP [Beta-84439] (Neves et al. 1999; Neves W, personal communication, 2000). Another joint program of research carried out between French and Brazilian archaeologists reported a suite of ${ }^{14} \mathrm{C}$ values obtained on charcoal samples recovered from a series of deeply stratified features, characterized as "hearths," in some cases containing chipped lithics interpreted as artifacts, at the site of Pedra Furada, a rock shelter situated in northeastern Brazil. An initial series of ${ }^{14} \mathrm{C}$ ages on the charcoal samples ranged from $6160 \pm 130 \mathrm{BP}$ [Gif-5863] to $41,500^{+4200} /{ }_{-3100}$ BP [Gif-7681] (Guidon and Delibrias 1986; Delibrias et al. 1988). The application of an ABOX (acid-base-wet oxidation) pretreatment followed by stepped combustion (Santos et al. 2001) to remove trace contamination on samples from the lower levels yielded significantly older finite values - the oldest obtained was 55,570 ${ }^{+1590}{ }_{-1320}$ BP [ANUA-16325] (Santos et al. 2003). As with the case with the Calico materials in California, an important issue in the evaluation of this site was not the general validity of age determinations - in this case the ${ }^{14} \mathrm{C}$ values - but rather the accuracy of the characterization of the chipped lithics as being the product of human agency. For Pedra Furada, there was also the question of the anthropogenic origin of the charcoal used to infer the presence of hearths.

As would be expected for a New World site containing materials purporting to demonstrate human presence at $>50,000 \mathrm{yr}$, varied and conflicted opinions have been offered as to the validity of the views of the site excavators. After visiting the site, 3 archaeologists with significant field experience in evaluating evidence from other New World Pleistocene age sites raised a number of questions concerning excavation strategies and other methodological issues. They called particular attention to the location of the site at the base of a cliff face. At the top of the cliff about $100 \mathrm{~m}$ over the occupation levels were quartzite-laden gravel bars and evidence that large quantities of water run-off from the top of the cliff face periodically cascaded down chutes leading to at least 2 parts of the site. The episodic water flow carried various-sized quartzite clasts, some of which, it was posited, had 
enough kinetic energy to facture materials at the cliff base. Their overall conclusion was that they were "skeptical of the claims for a Pleistocene [human] presence at Pedra Furada" (Meltzer et al. 1994:711). The Pedra Furada excavators took issue with many of the observations and most of the conclusions contained in Meltzer et al. The view that "pebble-tools would have suffered flaking when they fell from the plateau top" was characterized by them as "ridiculous." It was concluded that the criticisms offered by Meltzer et al. were based on "partial information and false data ... [and] a skepticism born of a subjective conviction" (Guidon et al. 1996).

${ }^{14} \mathrm{C}$ determinations on materials excavated from the Caverna da Pedra Pintada at Monte Alegre, Brazil, have been used to argue that the earliest human occupation at this site overlapped in time with Clovis in North America (Roosevelt et al. 1996). However, questions were immediately raised about several important aspects of the excavation data including alternative interpretations of the ${ }^{14} \mathrm{C}$ data (Tankersley 1997). A series of ${ }^{14} \mathrm{C}$ values obtained on materials from 6 purported or projected preClovis sites in Chile and Argentina has, with 1 exception, failed to support the suggested age. The exception is the site of Arroyo Seco 2, Argentina where ${ }^{14} \mathrm{C}$ determinations on Megatherium, Toixodon, Equus, and Hippidion bone samples dating in the range of 12,150 BP to 11,200 BP are suggested as representing an anthropogenic accumulation associated with marrow extraction and bone quarrying (Steele and Politis 2009).

In the late 1970s, Alan Bryan reported that a portion of a human skull from the Lagoa Santa region housed in Natural History Museum in Belo Horizonte, Brazil, exhibited "a very large and thick supraorbital ridge" suggesting that this trait might indicate significant age for the skull (Bryan 1978: 318-21; Beattie and Bryan 1984). It has subsequently been determined that the large brow ridges on this specimen had been faked (Anjos et al. 2005). According to information provided to M Beltrão, as reported in Beltrão et al. (2005), the thick ridges had been modeled on the cranium using a mixture of glue and plaster mixed with ground bone fragments and the resultant modeled surface was then painted to approximate the original color of the bone. At the time, it was viewed by Bryan, the facts associated with how the specimen had acquired its brow ridges apparently had not been known to the museum personnel and thus was not communicated to Bryan. This Logoa Santa skull might thus be regarded as the South American example of a "Piltdown-like" specimen.

Illustrations of intensive application of ${ }^{14} \mathrm{C}$ measurements to provide chronometric resolution for relative chronologies developed on the basis of ceramic seriation has been provided by the measurement of more than $100{ }^{14} \mathrm{C}$ values from sites associated with the Paracas and Nasca cultures on the southern coast of Peru. These archaeological cultures, dated to the period between about $800 \mathrm{BC}$ and $\mathrm{AD}$ 650, were responsible for the construction of the large geoglyphs on the desert pavement. In addition to wood, charcoal, textiles, and seeds, ${ }^{14} \mathrm{C}$ measurements were obtained on straw inclusions in adobe bricks widely used in building construction in the region (Unkel et al. 2007).

\section{SOUTH AMERICAN RADIOCARBON DATING CASE STUDY: MONTE VERDE, CHILE}

A revealing example of the influence of a relatively small ${ }^{14} \mathrm{C}$ data set from a single site on the course of archaeological discourse is illustrated by the implications of data from the site of Monte Verde, in the Lakes region of south-central Chile (Dillehay 1989, 1997a). Excavations beginning in 1976 recovered a wide-ranging cultural assemblage of wood, stone, fiber, and bone materials in what appears to be well-defined, multi-component, stratigraphic contexts with associated wood and charcoal samples.

Eleven ${ }^{14} \mathrm{C}$ measurements on a range of sample types from the upper or MV-II levels at the site ranged from 11,900 $\pm 120 \mathrm{BP}$ [TX-5376)] to 13,565 $\pm 250 \mathrm{BP}$ [TX-3208] (Nagle and Wilcox 1982). 
In discussing TX-3208, Dillehay and Pino (1989:140) first argued that it "may best represent the age of the cultural event, because it was sealed and preserved in a clay-lined feature ..." but later they rejected this date (Dillehay and Pino 1997a:48), basing their conclusion on the cluster of slightly younger dates from MV-II, which had been obtained subsequent to the analysis of TX-3208. If TX3208 is eliminated from consideration, the oldest value in this suite of values from MV-II is 12,780 \pm 240 BP (BETA-59082).

If the ${ }^{14} \mathrm{C}$ values from MV-II are, as whole, accepted as valid, this would indicate that the lithic artifact inventory from Monte Verde, which appears to have no developmental relationship to the Clovis assemblages of North America, was in place in a South American site approximately $1000{ }^{14} \mathrm{C}$ $\mathrm{yr}$ before the appearance of Clovis in North America. The acceptance of the validity of this conclusion renewed active discussions concerning the route(s) used by the earliest human populations as they moved south from presumed entry points in eastern Beringia. If a human population was indeed present on the coast of Chile a millennium prior to Clovis, the earliest migration route could be more reasonably sought along Pacific coastal zones and not immediately south below an ice-free Laurentide-Cordilleran corridor in North America. Regretfully, many of the sites where such evidence might be found would be under as much as $100 \mathrm{~m}$ of ocean as a consequence of the terminal Pleistocene-early Holocene rise in sea level.

Two ${ }^{14} \mathrm{C}$ values obtained from a lower "possible cultural level" at Monte Verde designed as MV-I raised concerns for those seeking to interpret the significance of the site. These 2 age determinations, reported as 33,370 $\pm 530 \mathrm{BP}$ (BETA-6754) and >33,020 BP (BETA-7825), were obtained on "charred" and "carbonized" wood (Dillehay and Pino 1997a:52). In addition to general questions of sample provenience throughout the site (e.g. Fiedel 1999; Dillehay et al. 1999, Collins 1999; Schmits 2004:72), there has been an extended discussion as to whether the MV-I materials associated with these 2 samples derive from cultural contexts (e.g. Adovasio and Pedler 1997:579; Dillehay 1997b; Dillehay and Collins 1991:339; Dillehay and Pino 1997b:36; Lynch 1990:27; Meltzer et al. 1997; Collins 1999; Dillehay et al. 1999).

As would be expected with such an important and controversial site, there has been considerable discussion of the integrity of the artifact assemblage including the quality of associations with some of the ${ }^{14} \mathrm{C}$ values at all levels in the site. Despite initial concerns (e.g. Haynes 1992:367), a number of the features and items interpreted as anthropogenic by excavators of the site associated with the ${ }^{14} \mathrm{C}$ values from MV-II have come to be regarded as the product of human agency by various specialists, although concerns have been continued to be expressed about the integrity of the stratigraphic contexts of the site with strong rejoinders by site excavators (Adovasio and Pedler 1997; Meltzer et al. 1997).

Potential problems with the validity of ${ }^{14} \mathrm{C}$ values from Monte Verde have been addressed in several studies. It is generally accepted that there is currently no reasonable basis on which to suspect major sample contamination given the range in sample types, the overall consistency in the values obtained, and the character of the sediments from which the samples were recovered (Pino and Dillehay 1988). However, 1 possible problem would present itself if there was a major terrestrial reservoir effect on samples from the vicinity of the site. The basis for this inference is that there are several active and extinct volcanoes situated along a north/south axis at the western base of the Cordillera de Los Andes. However, all of them are situated to the east and thus leeward of Monte Verde, with the closest located $\sim 65 \mathrm{~km}$ southeast of the site (Sinkin and Siebert 1994). Because prevailing winds consistently blow currently from the coastal zone located about $45 \mathrm{~km}$ to the west of the site, volcanic emissions from known volcanoes would not be expected to reach the region around Monte 
Verde. Even if wind patterns in the late Pleistocene were such that trace amounts of $\mathrm{CO}_{2}$-laden, ${ }^{14} \mathrm{C}$ "dead" magmatic gas might be present, attenuation factors would be significant and any postulated effect would be expected to produce, at most, a few hundred-year ago offset, unless, of course, a heretofore unknown magmatic vent existed within a few hundred meters of the site.

To evaluate the possibility of a reservoir effect at the site, measurements were obtained on modern organics growing at or near the site. The ${ }^{14} \mathrm{C}$ activity measured in the modern plants did not reveal any offset from expected contemporary ${ }^{14} \mathrm{C}$ values and thus provide no support for the existence of a terrestrial reservoir effect at least for the recent past (Taylor et al. 1999). Although there is, at present, no direct means of measuring potential ${ }^{14} \mathrm{C}$ reservoir offsets in the late Pleistocene for this region, there appears to be no compelling current data that would indicate that there have been major changes during geologically recent times.

An added argument for the absence of a major reservoir effect is the insistence that there is a consistency of the ${ }^{14} \mathrm{C}$ values from the site when compared against a chronology for the region as a whole (Porter 1981; Denton 1993). Against these arguments, Dickinson (2004) raised questions concerning the status of the ice cover at Monte Verde in relationship to where glacial ice lobes at 12,500 BP would have been situated. Haynes (1999) has suggested that some of the dated materials from the site might derive from outwash debris from permafrost zones. However, Chilean geologists familiar with the region have responded that their extensive studies lasting over several decades have, in their view, conclusively excluded such possibilities (literature cited in Dillehay and Pino 1997b; Dillehay T, personal communication, 2005).

Attention had also been called to a significant ${ }^{14} \mathrm{C}$ dating anomaly on a single sample from Monte Verde. In a set of ${ }^{14} \mathrm{C}$ dates reported under "non-cultural deposits," a ${ }^{14} \mathrm{C}$ age of $6550 \pm 160 \mathrm{BP}$ (BETA-7824) was assigned to a mastodon bone fragment that had been eroded out onto the surface in modern creek bed at the Monte Verde site (Dillehay and Pino 1997a:43-44, Table 3.1). In the same table under "cultural deposits," another ${ }^{14} \mathrm{C}$ date, 11,990 $\pm 200 \mathrm{BP}$ (TX-3760), was cited for a segment of mastodon bone excavated from the upper layer of a stratigraphic unit designated as MV6. However, these 2 bone segments were determined by the excavators to be "long-bone fragments that, fitting together, [came] from the same femur of a mastodon" (Dillehay and Pino 1989:136).

The excavators explained the approximately 5000-yr offset between the 2 segments of the same bone as the result of the contamination of BETA-7824 with modern organics. Taken at face value, it would mean that about $30 \%$ of the organics measured as BETA-7834 represented modern contamination. This is the approximate amount of contemporary, pre-bomb carbon required to produce an apparent ${ }^{14} \mathrm{C}$ age of $6500 \mathrm{BP}$ in a sample that should actually exhibit an age of $11,400 \mathrm{BP}$. If the contaminants were derived from atmospheric $\mathrm{CO}_{2}$ over the last $50 \mathrm{yr}$, then the percentage contamination could be as low as $20-25 \%$, since this very recent carbon would contain bomb ${ }^{14} \mathrm{C}$. Even so, such a relatively massive amount of contamination should have been largely removed by almost any standard bone pretreatment method used in most laboratories.

It was initially surmised that the $\sim 5000$-yr offset in the reported ages of the 2 segments of this Monte Verde mammoth bone might be, at least in part, traceable to a combination of very poor preservation of the collagen contained in 1 or both of these 2 bones and the differing content of recent exogenous organics for the 2 fragments arising from the very different depositional environments to which they were exposed. The older fragment (TX-3760) had been excavated in situ while the younger (BETA7824) had eroded out and the excavators concluded that it had laid on the surface for a considerable amount of time (Dillehay T, personal communication, 2005). 
Based on profiles of the constituent amino acids of both bone segments, it was determined that both had retained appreciable remnants of intact collagen, far above the levels where ${ }^{14} \mathrm{C}$ ages are typically problematic. For each bone segment, 2 different organic fractions-total amino acids and ultrafiltered gelatin - were chemically isolated. The ultrafiltration procedure provided $>10-\mathrm{kD}$ fractions and the yields from both bones indicated good collagen preservation and minimal cross-linking to exogenous carbohydrates or other chemical moieties. The ${ }^{14} \mathrm{C}$ values obtained on all 4 fractions - 2 amino acid and 2 ultrafiltered gelatin-from the 2 bone fragments yielded statistically identical ${ }^{14} \mathrm{C}$ values ranging from $12,455 \pm 40 \mathrm{BP}$ [UCIAMS-10738] to 12,510 $\pm 60 \mathrm{BP}$ [UCR-4014/ UCIAMS-2765] (George et al. 2005). Although the weighted average of the 4 values, 12,460 $( \pm 30)$ $\mathrm{BP}$, appears to be somewhat older than the previously reported age for TX-3760 of 11,990 $\pm 200 \mathrm{BP}$, the large experimental uncertainty cited for the earlier value makes a comparison difficult. However, it is clear that the original ${ }^{14} \mathrm{C}$ age assigned to the segment of the mastodon bone recovered from the surface of the site (BETA-7834) was erroneous. There is currently no explanation for this anomaly, unless the portion of the bone dated as BETA-7834 was far more biogeochemically degraded than the samples redated. Unfortunately, there are no data to confirm or refute this possibility.

\section{CONCLUSION}

Many commentators have noted that the most immediate and obvious impact of the ${ }^{14} \mathrm{C}$ method on the conduct of New World archaeological research in general was the ability of the technique to provide chronometric age estimates using - to a first-order approximation — a fixed-rate temporal scale that transcended local, regional, and even continental boundaries. A somewhat less recognized contribution to archaeological scholarship has been the fact that ${ }^{14} \mathrm{C}$-based age estimates provide a means of deriving chronological relationships independently of assumptions about assumed rates of cultural change and totally unrelated to any type of manipulation of archaeological materials (Willey and Phillips 1958:44; Dean 1978:226; Taylor 1978:63). When pressure to derive chronology primarily from the analyses of artifact data was released, inferences about the evolution of human behavior based on variations in environmental, ecological, or technological factors could be aggressively pursued employing an independently derived chronological framework. In the United States, the rise of the "New Archaeology" in the 1970s took place in this context. Lewis Binford has reflected that ${ }^{14} \mathrm{C}$ chronology "has certainly changed the activities of archaeologists, so that now, in many ways for the first time, they direct their methodological investments toward theory building rather than towards chronology building" (quoted in Gittins 1984:238).

At the inception of the method, Frederick Johnson offered a perspective that was as helpful 6 decades ago as it is today:

[P]rogress in the development of ... [radiocarbon dating] depends to a large degree upon the character of the collaboration [between archaeologists and other scientists]. The laboratory procedure involves theories in physics and chemistry which for the most part are outside the experience of almost everyone who has a sample to be dated. On the other hand, the results secured are of little consequence unless they are directly or indirectly related to some stratigraphic sequence. The value of the laboratory results is enhanced by critical evaluation by other scientists. Most particularly, the reverse is true. This involves continual examination of all basic theory and hypotheses by everyone concerned. The future value and usefulness of the method depends in large measure upon the success of continued collaboration between physicists, archaeologists, geologists, botanists, and others [Johnson et al. 1951:62].

${ }^{14} \mathrm{C}$ dating which, to again quote Frederick Johnson (1965:762), "dropped like an atomic bomb" on New World archaeology 6 decades ago, promises to continue to provide for generations of scholars 
to come, critical chronometric data for those concerned with understanding, from a scientific perspective, the evolution of prehistoric human societies in the New World. ${ }^{16}$

\section{APPENDIX I: INTERDISCIPLINARY ORIGINS OF RADIOCARBON DATING}

The origins and initial development of the ${ }^{14} \mathrm{C}$ method took place as the result of the intersections of multiple lines of interdisciplinary scientific investigations. Retrospectives reviewing how any scientific method came to be initially conceptualized and applied are, of necessity, selective reflecting the interests of the individuals undertaking the historical task. The task is also confronted, in some cases, with variability in the types of information and both the quality and quantity of the recollections of those who are the principal sources of information in cases where no primary notes made by principals are available for examination, especially if there is an interest on the part of some to either highlight or deemphasize some element or part of the previous work.

The origins of the ${ }^{14} \mathrm{C}$ method provides an illustration of these observations when we consider the narratives provided by 2 of the 3 individuals involved in the original research that established the foundations of ${ }^{14} \mathrm{C}$ dating, both of whom were chemists-Willard Libby [1909-1980] and James R Arnold [b. 1923]. ${ }^{17}$ In an interview in the late 1970s, Libby (1979) stated that the idea of using ${ }^{14} \mathrm{C}$ as a dating isotope occurred as a result of his reading a 1939 paper by Serge A Korff [1906-1989], a cosmic ray physicist, which argued that ${ }^{14} \mathrm{C}$ should exist in nature (Korff and Danforth 1939). Balloon experiments carried out by Korff had demonstrated the presence of neutrons at the top of Earth's atmosphere and predicted that the neutrons that did not escape into space would be slowed by collisions with atmosphere gas nuclei producing secondary or "thermal" neutrons, which would disappear by being captured by nitrogen to form ${ }^{14} \mathrm{C}$.

In placing Libby's comment in context, it is helpful to recall that ${ }^{14} \mathrm{C}$ is one of those isotopes which had been first artificially produced in a particle accelerator before experiments demonstrated that this isotope was being produced by natural processes in Earth's atmosphere. Both Kamen (1963) and Libby (1967) later noted that the first published suggestion of the existence of ${ }^{14} \mathrm{C}$ was contained in a paper by UC Berkeley physicist Franz Kurie [1907-1972] as what was initially viewed as a somewhat unlikely interpretation of the effect of neutron bombardment on nitrogen in a cloud chamber (Kurie 1934). By early 1940, Ruben and Kaman (1941), also at Berkeley, had determined that ${ }^{14} \mathrm{C}$ exhibited, as Currie (2003, 2004:186) has characterized it, the "wrong" half-life of $>1000 \mathrm{yr}$ rather than from a few minutes to, at most, a few months as previously assumed. ${ }^{18}$ They also deter-

${ }^{16}$ With perhaps a few exceptions, e.g. Lee (1981) and Gladwin (1976), the continuing source of objection to the general accuracy of the ${ }^{14} \mathrm{C}$ method since the late 1950 s have been based almost entirely on theological grounds most often expressed within a Protestant fundamentalist, young earth and/or young life creationist apologetic framework (e.g. Brown 1983, 1986). Scholarly reviews of the historical background to fundamentalist objections to ${ }^{14} \mathrm{C}$ dating and other scientific means of inferring temporal dimensions for the archaeological and geological record are contained in Numbers (1992) and, with a specific emphasis on American evangelical Protestant fundamentalists, in Yang (1993).

${ }^{17}$ The third researcher involved in the original ${ }^{14} \mathrm{C}$ work at Chicago with Libby was Ernest $\mathrm{C}$ Anderson [b. 1920]. Anderson was responsible for implementing the most critical component of the decay counting instrumentation used by Libby's group to measure natural levels of ${ }^{14} \mathrm{C}$ without recourse to isotopic enrichment, namely, anticoincidence counting, which provided a means of reducing the environmental background in the detectors. Without anticoincidence counting, routine decay counting-based ${ }^{14} \mathrm{C}$ measurements would not have been economically feasible to undertake due to the need to isotopically enrich every natural level ${ }^{14} \mathrm{C}$ sample (Taylor 1987:76-80, Figure 4.7). Anderson spent most of the remainder of his distinguished scientific career as a staff scientist at the University of California Los Alamos Science Laboratory.

${ }^{18}$ Nuclear structure theorists continue to comment that the relatively long half-life for ${ }^{14} \mathrm{C}$ continues to pose a problem to explain. The question is why ${ }^{14} \mathrm{C}$ should not have a half-life similar to ${ }^{11} \mathrm{C},{ }^{14} \mathrm{O},{ }^{15} \mathrm{O}$, or ${ }^{13} \mathrm{~N}$, which is a matter of minutes. Holt et al. (2008) cites various earlier explanations for ${ }^{14} \mathrm{C}$ beta decay suppression and posits a mechanism involving strong interactions of subatomic particles in the ${ }^{14} \mathrm{C}$ nucleus. 
mined that thermal neutron bombardment on nitrogen was the favored mode of production. Libby, also at Berkeley, knowing of the work of Ruben and Kaman, indicated that when he read the Korff and Danforth paper “. . . that's carbon dating” (Libby 1979:33). Thus, in his 1979 retrospective, Libby placed the genesis of his conceptualization of the ${ }^{14} \mathrm{C}$ dating model in 1939.

In a 1992 recollection, Arnold's recall of the discovery process suggested that the "idea [of ${ }^{14} \mathrm{C}$ dating] was certainly in Willard Libby's mind in 1946" (Arnold 1992:3). That year, Libby published a note in Physical Review entitled "Atmospheric helium three and radiocarbon from cosmic radiation." It would appear that Libby in this article introduced the word "radiocarbon" into the scientific lexicon. ${ }^{19}$ The text of the article begins "Nuclear physical data indicate that cosmic-ray neutrons produce $\mathrm{C}^{14}$ and $\mathrm{H}^{3}$ [tritium] from atmospheric nitrogen, the radiocarbon being the principal product" (Libby 1946:671 [symbols $\mathrm{C}^{14}$ and $\mathrm{H}^{3}$ used in original. text]).

In that paper, Libby cites 7 previous papers that "well established that neutron secondaries are produced in the atmosphere by the cosmic radiation." Interestingly, although 6 of the 7 papers cited by Libby following that sentence have Korff as a coauthor, the Korff and Danforth (1939) article is not included in the citation list. Libby goes on to observe that because the age of Earth is much greater than the mean life of ${ }^{14} \mathrm{C}$, "the rate of disintegration of $\left[{ }^{14} \mathrm{C}\right]$ is equal to the rate of production ..." and predicts the difference in ${ }^{14} \mathrm{C}$ content that should be exhibited by "biosphere carbon compounds" and "oil, coal, or limestone material."

If an actual "birthday" for ${ }^{14} \mathrm{C}$ dating is desired, Arnold later suggested that it might be identified as the day on which the first ${ }^{14} \mathrm{C}$ "date"-Chicago sample C-1, a piece of wood from the Step Pyramid of the Egyptian King Zoser at Sakkara - was actually calculated. Arnold still remembers that it was on 12 July 1948, a hot Chicago Saturday afternoon, that he had collected "enough counts from our still temperamental [solid carbon] system to calculate a preliminary result. I will never forget the impact of finding that it was about halfway between [the] contemporary wood values and the blank. For a couple of heady hours, I was the only person in the world who knew that ${ }^{14} \mathrm{C}$ dating worked. One lives for such moments" (Arnold 1992:6). ${ }^{20}$

\section{ACKNOWLEDGMENTS}

The author wishes to acknowledge the opportunity given to a first-year graduate student in archaeology at UCLA by the late Willard Libby to serve as a research assistant in his laboratory; the information provided by the late Frederick Johnson to understand the initial reactions of archaeologists in the United States to the introduction of ${ }^{14} \mathrm{C}$ dating; for the invaluable information about the operation of Libby's Chicago laboratory and other matters related to the early history of ${ }^{14} \mathrm{C}$ dating provided in multiple discussions with the author by James Arnold and Ernest Anderson; for a series of conversations with the late Rainer Berger that communicated information concerning various details

\footnotetext{
${ }^{19}$ As has been often noted (e.g. Taylor 1987:153), strictly speaking, "radiocarbon" is an imprecise term since there are other known radioactive isotopes of carbon $\left[{ }^{9} \mathrm{C}\right.$ through ${ }^{11} \mathrm{C}$ and ${ }^{15} \mathrm{C}$ through $\left.{ }^{20} \mathrm{C}\right]$ but they are all artificially produced in particle accelerators and have seconds or milliseconds half-lives. There is only one naturally-occurring radiocarbon, ${ }^{14} \mathrm{C}$.

${ }^{20}$ Arnold had received his PhD degree in physical chemistry form Princeton University working on the Manhattan Project. After completing his work with Libby at Chicago, he pioneered the development of liquid scintillation technology for lowlevel counting. He spent most of the remainder of his illustrious scientific career-he was elected to the United States National Academy of Sciences in 1964-as professor of chemistry at the University of California, San Diego (UCSD) including being the first to hold the Harold C Urey Professor of Chemistry (now emeritus) chair at UCSD. He worked primarily in the field of cosmogenic geochemistry and space and planetary science including participation in NASA's Apollo flights to the moon and conducting geochemical studies of lunar samples returned from those missions. An asteroid is named for him.
} 
about the interests of Willard Libby in archaeology and particularly in New World "Early Man" studies and his friendship with L S B Leakey; the long-term collaboration of John Southon first at the Center for Accelerator Mass Spectrometry, Lawrence Livermore National Laboratory, and now at the Keck Carbon Cycle Accelerator Mass Spectrometry Laboratory, University of California, Irvine; the very helpful comments provided by C Vance Haynes Jr, University of Arizona, on the Paleoamerican sections of this paper; and for the excellent, detailed comments of Jeffery S Dean, University of Arizona, on the entire manuscript. The author also wishes to thank the Gabrielle O Vierra Memorial Fund for support; Tom Stafford, Stafford Research Laboratories, Golden, Colorado for information on the organic fraction employed for the ${ }^{14} \mathrm{C}$ determination obtained on the Arroyo Frias human skeleton; Darden Hood, Beta Analytic, Inc., Miami, Florida, for information on the pretreatment method employed in obtaining the ${ }^{14} \mathrm{C}$ age determination and confirmation of the $\delta^{13} \mathrm{C}$ value obtained on this fraction of the "Confins Man" human skeleton; and Karl Taube, University of California, Riverside for information on the current status of oldest and youngest Maya monuments containing long-count inscriptions. Any and all errors of fact or interpretations are entirely the responsibility of the author.

\section{REFERENCES}

Adovasio JM, Pedler DR. 1997. Monte Verde and the antiquity of humankind in the Americas. American Antiquity 71:573-80.

Adovasio JM, Pedler DR. 2005. A long view of deep time at Meadowcroft Rockshelter. In: Bonnischsen R, Lepper BT, Stanford D, Waters MR, editors. Paleoamerican Origins: Beyond Clovis. College Station: Center for the Study of the First Americans, Texas A\&M University. p 23-8.

Adovasio JM, Gunn JD, Donahue J, Stuckenrath R. 1978. Meadowcroft Rockshelter, 1977: an overview. American Antiquity 43:632-51.

Adovasio JM, Donahue J, Stuckenrath R. 1980. Yes, Virginia, it really is that old: a reply to Haynes and Mead. American Antiquity 45:588-95.

Adovasio JM, Donahue J, Stuckenrath R. 1992. Never say never again: some thoughts on could haves and might have beens. American Antiquity 57:327-31.

Adovasio JM, Pedler DR, Donahue J, Stuckenrath R. 1998. Two decades of debate on Meadowcroft Rockshelter. North American Archaeologist 19:317-41.

Aikens CM. 1976. Cultural hiatus in the eastern Great Basin? American Antiquity 41:543-50.

Andrews Vth EW. 1978. Endnote: the northern Maya lowlands sequence. In: Taylor RE, Meighan CW, editors. Chronologies in New World Archaeology. New York: Academic Press. p 377-81.

Anjos MJ, Lopes RT, Mendonca de Souza MF, de Jesus FO. 2005. Investigation of a fossilized calotte from Lagoa Santa, Brazil by EDXRF X-ray spectrometry. X-ray Spectrometry 34:189-93.

Armitage RA, Brady JE, Cobb A, Southon JR, Rowe MW. 2001. Mass spectrometric radiocarbon dates from three rock paintings of known age. American Antiquity 66: 471-80.

Arnold JR. 1992. The early years with Libby at Chicago: a retrospective. In: Taylor RE, Long A, Kra RS, editors.
Radiocarbon After Four Decades An Interdisciplinary Perspective. New York: Springer-Verlag. p 3-10.

Arnold JR, Libby WF. 1950. Radiocarbon Dates (September 1, 1950). University of Chicago, Institute for Nuclear Studies.

Bacon CR. 1983. Eruptive history of Mount Mazama and Crater Lake Caldera, Cascade Range, U.S.A. Journal of Volcanology and Geothermal Research 18:57-115.

Bada JL, Helfman PM. 1975. Amino acid racemization dating of fossil bones. World Archaeology 7:160-83.

Bada JL, Schroeder RA, Carter GF. 1974. New evidence for the antiquity of man in North America deduced form aspartric acid racemization. Science 184(4138):791-3.

Baumhoff MA, Heizer RF. 1965. Postglacial climate and archaeology in the Desert West. In: Wright HE, Frey DG, editors. The Quaternary of the United States. Princeton: Princeton University Press. p 697-707.

Beattie OW, Bryan AL. 1984. A fossilized calotte with prominent browridges from Lagoa Santa, Brazil. Current Anthropology 25(3):345-6.

Beltrão M, Taylor RE, Kirner DL, Southon JR. 2005. Historical context and radiocarbon age of Logoa Santa human populations in Brazil. In: Dillon DB, Johnson KL, editors. Onward and Upward: Papers in Honor of Clement W. Meighan. Lancaster: Labyinthos. p 257-64.

Beramendi-Orosco L, Gonzalez-Hernandez G, Urrutia-Fucugauchi J, Manzanilla LR, Soler-Arechalde AM, Goguitchaishvil A, Jarboe N. 2009. High-resolution chronology for the Mesoamerican urban center of Teotihuacan derived from Bayesian statistics of radiocarbon and archaeological data. Quaternary Research 71(2):99-107.

Berger R. 1972. An isotopic and magnetic study of the Calico site. In: Schuiling WC, editor. Pleistocene Man at Calico. Redlands: San Bernardino County Museum. p 65-8.

Berger R. 1992. Libby's UCLA Radiocarbon Laboratory: contributions to archaeology. In: Taylor RE, Long A, Kra 
RS, editors. Radiocarbon After Four Decades: An Interdisciplinary Perspective. New York: Springer-Verlag. p 421-34.

Berger R, Libby WF. 1967. UCLA radiocarbon dates VI. Radiocarbon 9:477-504.

Berger R, Horney AG, Libby WF. 1964. Radiocarbon dating of bone and shell from their organic components. Science 144(3621):995-1001.

Berger R, Taylor RE, Libby WF. 1966. Radiocarbon content of marine shells from the California and Mexican West Coast. Science 153(3738):864-6.

Berger R, Protsch R, Reynolds R, Rozaire R, Sackett JR. 1971. New radiocarbon dates based on bone collagen of California. Contributions of the California Archaeological Research Facility 12:43-9.

Betancourt JL, Long A, Donahue DJ, Jull AJT, Zabel TH. 1984. Pre-Columbian age for North American Corispermum L. (Chenopodiaceae) confirmed by accelerator radiocarbon dating. Nature 311(5987):6535.

Bischoff JL, Childers WM. 1979. Temperature calibration of amino acid racemization: age implications for the Yuha skeleton. Earth and Planetary Science Letters 45(1):172-80.

Bischoff JL, Merriam R, Childers WM, Protsch R. 1976. Antiquity of man in America indicated by radiometric dates on the Yuha burial site. Nature 261(5556):128 9.

Bischoff JL, Ikeya M, Budinger FE. 1984. A TL/ESR study of the hearth feature at the Calico archaeological site, California. American Antiquity 49:764-74.

Bonatto SL, Salzano FM. 1997. A single and early migration for the peopling of the Americas supported by mitrochronmdrial DNA sequence data. Proceedings of the National Academy of Science USA 94(5):186671.

Bonnichsen R, Lepper BT. 2005. Changing perceptions of Paleoamerican prehistory. In: Bonnichsen R, Lepper BT, Stanford D, editors. Paleoamerican Origins: Beyond Clovis. College Station: Center for the Study of the First Americans, Texas A\&M University. p 919.

Bonnichsen R, Lepper BT, Stanford D, editors. 2005. Paleoamerican Origins: Beyond Clovis. College Station: Center for the Study of the First Americans, Texas A\&M University.

Brannon Jr HR, Daughtry AC, Perry D, Simons LH, Whitaker WW, Williams. 1957. Humble Oil Company radiocarbon dates I. Science 125(3239):147-50.

Broecker WS, Farrand WB. 1963. Radiocarbon age of the Two Creeks forest bed, Wisconsin. Geological Society of America Bulletin 74:795-802.

Bronk Ramsey C, Higham T, Bowles A, Hedges R. 2004. Improvements to the pretreatment of bone at Oxford. Radiocarbon 46(1):155-63.

Bronk Ramsey C, Buck CE, Manning SW, Reimer P, van der Plicht H. 2006. Developments in radiocarbon calibration for archaeology. Antiquity 80(310):783-98.
Brown RH. 1983. The interpretation of carbon-14 age data. In: Coffin HG. Origin by Design. Washington, DC: Review and Herald Publishing Association. p 241-95.

Brown RH. 1986. ${ }^{14} \mathrm{C}$ depth profiles as indicators of trends in climate and ${ }^{14} \mathrm{C} /{ }^{12} \mathrm{C}$ ratio. Radiocarbon 28(2A):350-7.

Brown TA, Nelson DE, Vogel JS, Southon JR. 1988. Improved collagen extraction by modified Longin method. Radiocarbon 30(2):171-7.

Brown TA, Quay PD, Francis RC, Holmgren D. 1998. Radiocarbon as tracer and chronometer: advances and applications of radiocarbon to climate and carbon cycle studies. Eos, Transactions, American Geophysical Union 79:5167.

Bryan AL. 1978. An overview of Paleo-American prehistory from a circum-Pacific perspective. In: Bryan $\mathrm{AL}$, editor. New Evidence for the Pleistocene Peopling of the Americas. Edmonton: Department of Anthropology, University of Alberta. p 13-37.

Buck AL. 1983. A History of the Atomic Energy Commission. Washington, DC: US Department of Energy.

Butler BP. 1961. The Old Cordilleran culture in the Pacific Northwest. Occasional Papers of the Idaho State College Museum 5. Pocatello, Idaho.

Byers DS, editor. 1967-1972. Prehistory of the Tehuacan Valley. 4 volumes. Austin: University of Texas Press.

Chatters JC. 2000. The recovery and first analysis of an Early Holocene human skeleton from Kennewick, Washington. American Antiquity 65:291-316.

Chatters JC. 2001. Ancient Encounters: Kennewick Man and the First Americans. New York: Simon \& Schuster.

Chisholm BS, Nelson DE, Schwarcz HP. 1982. Stablecarbon isotope ratios as a measure of marine versus terrestrial protein in ancient diets. Science 216(4550): $1131-2$.

Chrisman D, MacNeish RS, Mavalwala J, Savage H. 1996. Late Pleistocene human friction skin prints from Pendejo Cave, New Mexico. American Antiquity 61: 357-76.

Clark JD. 1979. Radiocarbon dating and African archaeology. In: Berger R, Suess HE, editors. Radiocarbon Dating. Berkeley: University of California Press. p 731.

Cline HF, editor. 1972. Guide to Ethnohistoric Sources, Parts 1-2. Handbook of Middle American Indians. Volumes 12-13. Austin: University of Texas Press.

Coe MD, Diehl RA. 1980. In the Land of the Olmec: The Archaeology of San Lorenzo Tenochititlan. 2 volumes. Austin: University of Texas Press.

Collins MB. 1999. Reply to Fiedel, part II. Discovering Archaeology 1(6):14-5.

Collins MB, Waters MR, Goodyear AC, Stanford DJ, Pertierra T, Goebel T. 2008. 2008 Paleoamerican Origins workshop: a brief report. Current Research in the Pleistocene 25:195-7.

Conrad N, Asch DL, Asch NB, Elmore D, Gove H, Rubin 
M, Brown JA, Wiant MD, Farnsworth KB, Cook TG. 1984. Accelerator radiocarbon dating of evidence for prehistoric horticulture in Illinois. Nature 308(5958): 443-6.

Cowgill GL. 2008. An update on Teotihuacan. Antiquity 82(318):962-75.

Crook Jr WW, Harris RK. 1958. A Pleistocene campsite near Lewisville, Texas. American Antiquity 23:23346.

Currie LA. 2003. The remarkable metrological history of ${ }^{14} \mathrm{C}$ dating: from ancient Egyptian artifacts to particles of soot and grains of pollen. Czechoslovak Journal of Physics 53:A137-A160.

Currie LA. 2004. The remarkable metrological history of radiocarbon dating [II]. Journal of Research of the $\mathrm{Na}$ tional Institute of Standards and Technology 109:185217.

Daniel G. 1967. The Origin and Growth of Archaeology. New York: Crowell.

Dean JS. 1978. Independent dating in archaeological analysis. In: Schiffer MB, editor. Advances in Archae ological Method and Theory. New York: Academic Press. p 223-65.

Delibrias G, Guidon N, Parenti F. 1988. The Toca do Boqueirao do Sitio da Pedra Furada: stratigraphy and chronology. In: Early Man in the Southern Hemisphere. Supplement to Archaeometry: Australasian Studies. Adelaide: University of Adelaide.

de Messières N. 2001. Libby and the interdisciplinary aspect of radiocarbon dating. Radiocarbon 43(1):1-5.

Denton G. 1993. The Quaternary of the Lake District of Southern Chile Field Guide. Santiago: International Workshop on the Quaternary of Chile. p 52-70.

de Vries H. 1958. Variation in concentration of radiocarbon with time and location on Earth. Proceedings Koninklijke Nederlandse Akademie van Wetenschappen Series B 61(2):94-102.

Diaz-Granádos C, Rowe MW, Hyman M, Duncan J, Southon JR. 2001. AMS radiocarbon dates for charcoal from three Missouri pictographs and their associated iconography. American Antiquity 66:481-92.

Dick HW. 1965. Bat Cave. School of American Research Monograph No. 27.

Dickinson WR. 2004. Migration pathways. American Geological Institute. Geotimes 10:6.

Dillehay TD. 1989. Monte Verde: A Late Pleistocene Settlement in Chile. Volume 1. Paleoenvironment and Site Context. Washington, DC: Smithsonian Institution Press.

Dillehay TD. 1997a. Monte Verde: A Late Pleistocene Settlement in Chile. Volume 2. The Archaeological Context and Interpretation. Washington, DC: Smithsonian Institution Press.

Dillehay TD. 1997b. Site findings: activity patterning of the archaeological remains. In: Dillehay TD. Monte Verde: a Late Pleistocene Settlement in Chile. Volume 2. The Archeological Context and Interpretation.
Washington, DC: Smithsonian Institution Press. p 767-88.

Dillehay TD, Collins MB. 1992. Monte Verde, Chile: a comment on Lynch. American Antiquity 56:333-41.

Dillehay TD, Pino N. 1989. Stratigraphy and chronology. In: Dillehay TD. Monte Verde: a Late Pleistocene Settlement in Chile. Volume 1. Paleoenvironment and Site Context. Washington, DC: Smithsonian Institution Press. p 133-45.

Dillehay TD, Pino M. 1997a. Radiocarbon chronology. In: Dillehay TD. Monte Verde: a Late Pleistocene Settlement in Chile. Volume 2. The Archaeological Context and Interpretation. Washington, DC: Smithsonian Institution Press. p 41-52.

Dillehay TD, Pino M. 1997b. Site setting and strategy. In: Dillehay TD. Monte Verde: a Late Pleistocene Settlement in Chile. Volume 2. The Archeological Context and Interpretation. Washington, DC: Smithsonian Institution Press. p 25-40.

Dillehay TD, Pino M, Rossen J, Ocampo C, Rivas P, Pollack D, Henderson G. 1999. Reply to Fiedel, part 1. Discovering Archaeology [Special Report] 1(6):12-4.

Dincauze D. 1981. The Meadowcroft papers. Quarterly Review of Archaeology 2:(1):3-4.

Dixon EJ. 1999. Bones, Boats, \& Bison: Archaeology and the First Colonization of Western North America. Albuquerque: University of New Mexico Press.

Dixon EJ, Heaton TH, Fifield TE, Hamilton TD, Putnam DE, Grady F. 1997. Late Quaternary regional geoarchaeology of Southeast Alaska karst: a progress report. Geoarchaeology 12(6):689-712.

Downey R. 1999. Riddle of the Bones: Politics, Science, Race, and the Story of the Kennewick Man. New York: Copernicus.

Drucker P, Heizer RF, Squier RJ. 1957. Radiocarbon dates from La Venta, Tabasco. Science 126(3263):723.

Duplessy JC, Arnold M. 1989. Radiocarbon dating by accelerator mass spectrometry. In: Roth E, Poty B, editors. Nuclear Methods of Dating. Dordrecht: Kluwer Academic Publishers. p 437-54.

Ennis P, Noltmann EA, Hare PE, Slota Jr PJ, Payen LA, Prior CA, Taylor RE. 1986. Use of AMS analysis in the study of problems in aspartic acid racemization-deduced age estimates on bone. Radiocarbon 28(2A):539-46.

Fagan JL. 1999. Analysis of lithic artifact embedded in the Columbia Park remains. Archeology \& Ethnography Program, National Park Service, US Department of Interior. http://www.cr.nps.gov/aad/kennewick/fagan.htm.

Fagundes NJR, Kanitz R, Eckert R, Valls ACS, Bogo MR, Salzano FM, Smith DG, Silva Jr SA, Zago MA, Riberiro-dos-Santos AK, Santos SEB, Luiza PetziErier L, Bonatto SL. 2008. Mitochondrial population genomics supports a single Pre-Clovis origin with a coastal route for the peopling of the Americas. The 
American Journal of Human Genetics 82:583-92.

Faught MK. 2008. Archaeological roots of human diversity in the New World: a compilation of accurate and precise radiocarbon ages from earliest sites. American Antiquity 73:670-98.

Fedick SL, Taube KA. 1992. The role of radiocarbon dating in Maya archaeology: four decades of research. In: Taylor RE, Long A, Kra RS, editors. Radiocarbon After Four Decades: An Interdisciplinary Perspective. New York: Springer-Verlag. p 403-20.

Fiedel SJ. 1999. Artifact provenience at Monte Verde: confusion and contradictions. Discovering Archaeology [Special Report] 1(6):1-12.

Fiedel SJ. 2000. The peopling of the New World: present evidence, new theories, and future directions. Journal of Archaeological Research 8:39-103.

Fiedel SJ. 2004a. Initial human colonization of the Americas: an overview of the issues and the evidence. $R a$ diocarbon 44(2):407-36.

Fiedel SJ. 2004b. The Kennewick follies: "new" theories about the peopling of the Americas. Journal of Archaeological Research 60:75-110.

Fiedel SJ. 2006. Points in time: establishing a precise hemispheric chronology for Paleoindian migrations. In: Morrow JE, Guesso C, editors. Paleoindian Archaeology: A Hemispheric Perspective. Gainesville: University of Florida Press. p 21-43.

George D, Southon JR, Taylor RE. 2005. Resolving an anomalous radiocarbon determination on mastodon bone from Monte Verde, Chile. American Antiquity 70:764-70.

Gittins GO. 1984. Radiocarbon chronometry and archaeological thought [PhD dissertation]. University of California, Los Angeles.

Gladwin HS. 1976. Dendrochronology, radiocarbon, and bristlecones. Anthropological Journal of Canada 14: 2-7.

Goebel T, Waters MR, O'Rourke DH. 2008. The late Pleistocene dispersal of modern humans in the Americas. Science 319(5869):1497-502.

Goldberg P, Arkin TL. 1999. Micromorphological analysis of sediments from Meadowcroft Rockshelter, Pennsylvania: implications for radiocarbon dating Journal of Field Archaeology 26:325-42.

Gonzalez S, Jiménez-Lopez JC, Hedges R, Huddart D, Ohman JC, Turner T, Pompa y Padilla JA. 2003. Earliest humans in the Americas: new evidence from México. Journal of Human Evolution 44(3):379-87.

Green TJ, Cochran B, Fenton TW, Woods JC, Titmus GL, Tieszen L, Davis MA, Miller SJ. 1998. The Buhl Burial: a Paleoindian woman from southern Idaho. American Antiquity 63:457-67.

Griffin J. 1946. Cultural change and continuity in eastern United States archaeology. In: Johnson F, editor. Man in Northeastern North America. Papers of the Robert S. Peabody Foundation for Archaeology 3. p 37-95.

Griffin J. 1952. Archaeology of the Eastern United States. Chicago: University of Chicago Press.
Griffin J. 1965. Radiocarbon dating and the cultural sequence in the eastern United States. In: Chatters RM, Olson EA, compilers. Proceedings of the Sixth International Conference Radiocarbon and Tritium Dating. Springfield: Clearinghouse for Federal Scientific and Technical Information. p 117-30.

Griffin J. 1967. Eastern North American archaeology: a summary. Science 156(3772):175-91.

Griffin J. 1968. Northeast Asian and northwestern American ceramics. Proceedings of the VIII ${ }^{\text {th }}$ International Congress of Anthropological and Ethnological Sciences 3:327-30.

Griffin J. 1978. Eastern United States. In: Taylor RE, Meighan CW, editors. Chronologies in New World Archaeology. New York: Academic Press. p 51-70.

Groot C, Margolis L, editors. 1991. Pacific Salmon Life Histories. Vancouver: University of British Columbia Press

Guidon N, Delibrias G. 1986. Carbon-14 dates point to man in the Americas 32,000 years ago. Nature 321(6072):769-71

Guidon N, Pessis A-M, Parenti F, Fontugue M, Guérin C. 1996. Nature and age of the deposits in Pedra Furada, Brazil: reply to Meltzer, Adovasio, and Dillehay. Antiquity 70(268):408-21.

Haas H, Holliday V, Stuckenrath R. 1986. Dating of Holocene stratigraphy with soluble and insoluble organic fractions at the Lubbock Lake archaeology site, Texas: an ideal case study. Radiocarbon 28(2A):473-85.

Hallet DJ, Hills LV, Clague JJ. 1997. New accelerator mass spectrometry radiocarbon ages for the Mazama tephra layer from Kootenay National Park, British Columbia, Canada. Canadian Journal of Earth Sciences 34:1202-9.

Hard RJ, Roney JR. 1998. A massive terraced village complex in Chihuahua, Mexico, 3000 years before present. Science 279(5357):1661-4.

Harrington MR. 1954. The oldest camp-fires. The Masterkey 28:233-4.

Harrington MR, Simpson RE. 1961. Tule Springs, Nevada with other evidence of Pleistocene man in North America. Southwest Museum Papers. No. 18. Los Angeles: Southwest Museum.

Hart JP, Scarry C. 1999. The age of common beans (Phaseolus vulgaris) in the northeastern United States. American Antiquity 64:653-8.

Haynes Jr CV. 1965. Carbon-14 dates and early man in the new world. In: Chatters RM, Olson EA, compilers. Proceedings of the Sixth International Conference on Radiocarbon and Tritium Dating. Springfield: Clearinghouse for Federal Scientific and Technical Information. p 145-64.

Haynes Jr CV. 1967. Quaternary geology of the Tule Springs area, Clark County, Nevada. In: Wormington HM, Ellis D, editors. Pleistocene Studies in Southern Nevada. Nevada State Museum Anthropological Papers, No. 13. Carson City: Nevada State Museum. p 14-104. 
Haynes Jr CV. 1973. The Calico site: artifacts or geofacts? Science 181(4097):305-10.

Haynes Jr CV. 1980. Paleoindian charcoal from Meadowcroft Rockshelter: Is contamination a problem? American Antiquity 45:582-7.

Haynes Jr CV. 1984. Stratigraphy and late Pleistocene extinctions in the United States. In: Martin PS, Klein RG, editors. Quaternary Extinctions: A Prehistoric Revolution. Tucson: University of Arizona Press. p 345-55.

Haynes Jr CV. 1988. Geofacts and fancy. Natural History 288:4-12.

Haynes Jr CV. 1991a. Geoarchaeological and paleohydrological evidence for a Clovis-age drought in North America and its bearing on extinction. Quaternary Research 35:438-50.

Haynes Jr CV. 1991b. More on Meadowcroft radiocarbon chronology. The Review of Archaeology 12:8-14.

Haynes Jr CV. 1992. Contributions of radiocarbon dating to the geochronology of the peopling of the New World. In: Taylor RE, Kra R, Long A, editors. Radiocarbon After Four Decades: An Interdisciplinary Perspective. New York: Springer-Verlag. p 355-74.

Haynes Jr CV. 1999. Monte Verde and the pre-Clovis situation in America. Discovering Archaeology/Scientific American 1(6):17-19.

Haynes Jr CV. 2005. Clovis, pre-Clovis, climate change, and extinction. In: Bonnichsen R, Lepper BT, Stanford D, Waters MR, editors. Paleoamerican Origins: Beyond Clovis. College Station: Center for the Study of the First Americans, Texas A\&M University. p 11332.

Haynes Jr CV, Agogino G. 1960. Geological significance of a new radiocarbon date from the Lindenmeier site. Denver Museum of Natural History Proceedings. No. 9. Denver: Denver Museum of Natural History.

Haynes Jr CV, Doberenz AR, Allen JA. 1966. Geological and geochemical evidence concerning the antiquity of bone tools from Tule Springs, site 2, Clark County, Nevada. American Antiquity 31:517-21.

Haynes G. 2002. The Early Settlement of North America: The Clovis Era. Cambridge: Cambridge University Press.

Haynes G, Anderson DG, Ferring CR, Fiedel SJ, Grayson DK. Haynes Jr CV, Holliday VT, Buckell BB, Kornfeld M, Meltzer DJ, Morrow J, Suroveli T, Waguespack NM, Wigand, P Yohe RM. 2007. Comment on "Redefining the age of Clovis: implications for the peopling of the Americas." Science 317(5836):320.

Hedges REM, Law IA. 1989. The radiocarbon dating of bone. Applied Geochemistry 4:229-33.

Hedges REM, Van Klinken GJ. 1992. A review of current approaches in the pretreatment of bone for radiocarbon dating by AMS. Radiocarbon 34(3):279-91.

Heizer RF, Brooks RA. 1965. Lewisville-ancient campsite or wood rat houses? Southwestern Journal of Anthropology 21:155-65.
Heizer RF, Hester TR. 1978. Great Basin. In: Taylor RE, Meighan CW, editors. Chronologies in New World Archaeology. New York: Academic Press. p 147-99.

Hester TR. 1973. Chronological ordering of Great Basin prehistory. University of California Archaeological Research Facility Contributions 17. Berkeley: University of California.

Higham TFG, Jacobi RM, Bronk Ramsey C. 2006. AMS radiocarbon dating of ancient bone using ultrafiltration. Radiocarbon 48(2):179-95.

Holliday V, Johnson E. 1986. Reevaluation of the first radiocarbon age for the Folsom culture. American Antiquity 51:332-8.

Holt JW, Brown GE, Kuo TTS, Holt JD, Machleidt R. 2008. Shell model description of the ${ }^{14} \mathrm{C}$ dating $\beta$ decay with Brown-Rho-Scaled NN interactions. Physical Review Letters 100(6):2501.

Hrdlička A, Holmes WH, Willis B, Wright PE, Fenner CN. 1912. Early man in South America. Bureau of American Ethnology 52:153-395. Washington, DC: Smithsonian Institution.

Huckleberry G, Stein JK. 1999. Analysis of sediments associated with human remains found at Columbia Park, Kennewick, WA. Archeology \& Ethnography Program, National Park Service, US Department of Interior. http://www.cr.nps.gov/aad/kennewick/ huck_stein.htm.

Huckleberry G, Stafford TW, Chatters JC. 1998. Preliminary geoarchaeological studies at Columbia Park, Kennewick, Washington, USA. Report submitted to the US Army Corps of Engineers, Walla Walla District, 23 March 1998.

Hurt W. 1960. The cultural complexes from the Lagoa Santa region, Brazil. American Anthropologist 62: 569-85.

Irving WN. 1985. Context and chronology of early man in the Americas. Annual Review of Anthropology 14: 529-55.

Irving WN, Harrington CR. 1973. Upper Pleistocene radiocarbon-dated artifacts from the Northern Yukon. Science 179(4071):335-40.

Jantz RL, Owsley DW. 1997. Pathology, taphonomy and cranial morphometrics of the Spirit Cave Mummy. Nevada Historical Society Quarterly 40:57-61.

Johnson F. 1955. Reflections upon the significance of radiocarbon dates. In: Libby WF. Radiocarbon Dating. 2nd edition. Chicago: University of Chicago Press. p 141-61.

Johnson F. 1965. The impact of radiocarbon dating upon archaeology. In: Chatters RM, Olson EA, compilers. Proceedings of the Sixth International Conference Radiocarbon and Tritium Dating. Springfield: Clearinghouse for Federal Scientific and Technical Information. p 762-80.

Johnson F, MacNeish RS. 1972. Chronology of the Tehuacan Valley. In: Byers DS, editor. Prehistory of the Tehuacan Valley. Volume 4. Austin: University of Texas 
Press.

Johnson F, Willis EH. 1970. Reconciliation of radiocarbon and sideral years in Meso-American chronology. In: Olsson IU, editor. Radiocarbon Variations and $A b-$ solute Chronology. Stockholm: Almqvist \& Wiksell. p 93-104.

Johnson F, Rainey F, Collier D, Flint RF. 1951. Radiocarbon dating, a summary. In: Radiocarbon Dating. Memoirs of the Society for American Archaeology 8: 59-63. [American Antiquity 17(1, part 2):59-63].

Johnson JR, Stafford TW, Ajie HO, Morris DP. 2000. Arlington Springs revisited. In: Browne D, Mitchell K, Chaney H, editors. Proceedings of the Fifth California Islands Symposium. Santa Barbara: Santa Barbara Museum of Natural History. p 541-5.

Kamen MD. 1963. Early history of carbon-14. Science 140(3567):584-90.

Kaufman TS. 1980. Early prehistory of the Clear Lake area, Lake County, California [PhD dissertation]. University of California, Los Angeles.

Kelley DH. 1983. The Maya calendar correlation problem. In: Leventhal RM, Lolata LM, editors. Civilization in the Ancient Americas, Essays in Honor of Gordon R. Willey. Albuquerque: University of New Mexico Press. p 157-86.

Kemp BM, Malhi RS, McDonough J, Bolnick DA, Eshleman JA, Richards O, Martinez-Labarga C, Johnson JR, Lorenz JG, Dixon EJ, Fifield TE, Heaton TH, Wori R, Smith DG. 2007. Genetic analysis of early Holocene skeletal remains from Alaska and its implications for the settlement of the Americas. American Journal of Physical Anthropology 132:606-21.

Kirner DL, Burky R, Taylor RE, Southon JR. 1997. Radiocarbon dating organic residues at the microgram level. Nuclear Instruments and Methods and Physics Research B 123(1-4):214-7.

Knezovich J, Brown T, Buchholz B, Finkel R, Guilderson T, Kashgarian M, Nimz G, Ognibene T, Turney S, Vogel J, editors. 2007. Accelerator Mass Spectrometry. Proceedings of the Tenth International Conference on Accelerator Mass Spectrometry, Berkeley, California, USA, 5-10 September 2005. Nuclear Instruments and Methods in Physics Research B 259:1-816.

Korff SA, Danforth WE. 1939. Neutron measurements with boron-trifluoride counters. Physical Review 55: 980.

Kovar AJ. 1966. Problems in radiocarbon dating at Teotihuacan. American Antiquity 31:427-30.

Kuehn SC, Froese DG, Carrara PE, Foit Jr FF, Pearce NJG, Rotheisler P. 2009. Major- and trace-element characterization, expanded distribution, and a new chronology for the latest Pleistocene Glacier Peak tephras in western North America. Quaternary Research 71(2):201-16.

Kulp JL, Feely HW, Tryon LE. 1951. Lamont natural radiocarbon measurements, I. Science 114(2970):5658.
Kurie FND. 1934. A new mode of disintegration induced by neutrons. Physical Review 45:904-5.

Leakey LSB, Simpson RD, Clements T. 1968. Archaeological excavations in the Calico Mountains, California: preliminary report. Science 160(3831):1022-3.

Leakey M. 1984. Disclosing the Past. Garden City: Doubleday \& Company.

Leavitt SW, Kalin RM. 1992. A new tree-ring width, $\delta^{13} \mathrm{C}$ and ${ }^{14} \mathrm{C}$ investigation of the Two Creeks site. $\mathrm{Ra}$ diocarbon 34(3):792-7.

Lee RE. 1981. Radiocarbon ages in error. Anthropological Journal of Canada 19:9-29.

Leonhardy FC, Rice DG. 1970. A proposed culture typology for the Lower Snake River region, southwestern Washington. Northwest Anthropology Research Notes 4(1):1-29.

Libby WF. 1946. Atmospheric helium three and radiocarbon from cosmic radiation. Physical Review 69: 671-2.

Libby WF. 1951. Radiocarbon dates, II. Science 114(2960):291-6.

Libby WF. 1952. Radiocarbon Dating. Chicago: University of Chicago Press.

Libby WF. 1954. Chicago radiocarbon dates V. Science 120(3123):733-42.

Libby WF. 1955. Radiocarbon Dating. 2nd edition. Chicago: University of Chicago Press.

Libby WF. 1967. History of radiocarbon dating. In: $R a-$ dioactive Dating and Methods of Low Level Counting. Vienna: International Atomic Energy Agency. p 3-25.

Libby WF. 1979. Interview with W. F. Libby, April 12, 1979 on file at the Center for the History of Physics, American Institute of Physics.

Little EA. 2002. Kautantouwit's legacy: calibrated dates on prehistoric maize in New England. American Antiquity 67:109-18.

Long A, Benz BF, Donahue DJ, Jull AJT, Toolin LJ. 1989. First direct AMS dates on early maize from Tehuacán, Mexico. Radiocarbon 31(3):1035-40.

Lyman RL, O'Brien MJ. 2006. Measuring Time with Artifacts. Lincoln: University of Nebraska Press.

Lynch TF. 1990. Glacial-age man in South America: a critical review. American Antiquity 55:12-36.

MacNeish RS. 1996. Federick Johnson 1904-1994 (obituary). American Antiquity 61:269-73.

MacNeish RS, Libby JG. 2003. Pendejo Cave. Albuquerque: University of New Mexico Press.

Madsen DB, Berry MS. 1975. A reassessment of northeastern Great Basin prehistory. American Antiquity 40:391-405.

Marlowe G. 1980. W F Libby and the archaeologists, 1946-1948. Radiocarbon 22(3):1005-14.

McManamon FP. 1999a. The initial scientific examination, description, and analysis of the Kennewick Man human remains. Archeology \& Ethnography Program, National Park Service, US Department of Interior. http: //www.cr.nps.gov/aad/kennewick/mcmanamon.htm. 
McManamon FP. 1999b. Determination that the Kennewick human skeletal remains are "Native American" for the purposes of the Native American Graves Protection and Repatriation Act (NAGPRA). Archeology \& Ethnography Program, National Park Service, US Department of Interior. http:// www.cr.nps.gov/aad/kennewick/c14memo.htm.

Mead JI. 1980. Is it really that old? A comment about the Meadowcroft Rockshelter "Overview." American Antiquity 45:579-83.

Mehringer PJ, Foit FF. 1990. Volcanic ash dating of the Clovis cache at East Wenatchee, Washington. $\mathrm{Na}$ tional Geographic Research 6:495-503.

Meltzer DJ. 1989. Why don't we know when the first people came to North America? American Antiquity 54:471-90.

Meltzer DJ. 2004. Peopling of North America. In: Gillespie AR, Porter SC, Atwater BF, editors. The Quaternary Period in the United States. Amsterdam: Elsevier. p 539-64.

Meltzer DJ, Adovasio JM, Dillehay TD. 1994. On a Pleistocene human occupation at Pedra Furada, Brazil. Antiquity 68(261):695-714.

Meltzer DJ, Grayson DK, Ardile G, Barker AW, Dincauze DF, Haynes Jr CV, Mena F, Nunez L, Stanford DJ. 1997. On the Pleistocene antiquity of Monte Verde, southern Chile. American Antiquity 62:65963.

Meltzer DJ, Todd LC, Holliday VT. 2002. The Folsom (Paleoindian) type site: past investigations, current studies. American Antiquity 67:5-36.

Minnis PE. 1992. Earliest plant cultivation in the desert borderlands of North America. In: Cowan CW, Watson PJ, editors. The Origins of Agriculture. Washington, DC: Smithsonian Institution Press. p 121-41.

Nagle C, Wilcox UV. 1982. Monte Verde: radiocarbon dates from an early-man site in south-central Chile. Journal of Field Archaeology 9:547-50.

Nash SE. 2000. Seven decades of archaeological treering dating. In: Nash SE, editor. It's About Time: A History of Archaeological Dating in North America. Salt Lake City: University of Utah Press. p 60-82.

Nash SE, Dean JS. 2000. The surprisingly deficient history of archaeochronology. In: Nash SE, editor. It's About Time: A History of Archaeological Dating in North America. Salt Lake City: University of Utah Press. p 2-11.

Nelson CM. 1969. The Sunset Creek site (45-KT-28) and its place in Plateau prehistory. Reports of Investigations, No. 47. Pullman: Washington State University Laboratory of Anthropology.

Nelson DE, Moreland RE, Vogel JS, Southon JR, Harington CR. 1986. New dates on northern Yukon artifacts: Holocene not Upper Pleistocene. Science 232(4751): $749-51$.

Nelson NC. 1933. The antiquity of man in America in the light of archaeology. In: Jenness D, editor. The Amer- ican Aborigines, Their Origins and Antiquity. Toronto: University of Toronto Press. p 87-130.

Neustupný E. 1970. The accuracy of radiocarbon dating. In: Olsson IU, editor. Radiocarbon Variations and Absolute Chronology. Stockholm: Almqvist \& Wiksell. p 23-34.

Neves WA, Hubbe E. 2005. Cranial morphology of early Americans from Lagoa Santa, Brazil: implications for the settlement of the New World. Proceedings of the National Academy of Sciences USA 102(51):18,30914.

Neves WA, Powell JF, Prous A, Ozolins EG, Blum M. 1999. Lapa Vermelha IV hominid 1: morphological affinities of the earliest known American. Genetics and Molecular Biology 22(4):1-13.

Newman TM. 1966. Cascadia Cave. Occasional Papers of the Idaho State Museum 18. Pocatello, Idaho, USA.

Nickens PR. 1998. Discovery and recovery of human remains from the Columbia Park Site, Kennewick, WA, July-September 1996. Report prepared for the US Department of Justice, Environmental and Natural Resources Division, Washington, DC.

Nitecki MH, Nitecki V, editors. 1994. Origins of Anatomically Modern Humans. New York: Plenum Press.

Numbers R. 1992. The Creationists: The Evolution of Scientific Creationism. New York: A.A. Knopf.

Olsson IU, editor. Radiocarbon Variations and Absolute Chronology. Stockholm: Almqvist \& Wiksell.

Payen LA. 1982. The pre-Clovis of North America: temporal and artifactual evidence [PhD dissertation]. University of California, Riverside.

Payen L, Taylor RE. 1977. Man and Pleistocene fauna at Potter Creek Cave, California. Journal of California Anthropology 3:51-8.

Phillips P, Ford J, Griffin JB. 1951. Archaeological survey in the lower Mississippi alluvial valley 19401947. Papers of the Peabody Museum of American Archaeology and Ethnology. Volume 25. Cambridge: Peabody Museum.

Pino MQ, Dillehay TD. 1988. Monte Verde, south-central Chile: stratigraphy, climate change, and human settlement. Geoarchaeology 3(3):177-91.

Porter SC. 1978. Glacier Peak tephra in the North Cascade Range, Washington: stratigraphy, distribution, and relationship to late-glacial events. Quaternary Research 10(1):30-41.

Porter SC. 1981. Pleistocene glaciation in the southern Lake District of Chile. Quaternary Research 16(3): 263-92.

Powell JF, Rose JC. 1999. Report on the osteological assessment of the "Kennewick Man" skeleton (CENWW.97.Kennewick). Archeology \& Ethnography Program, National Park Service, US Department of Interior. http://www.cr.nps.gov/aad/kennewick/ Powell_rose.htm.

Ralph EK. 1965. Review of radiocarbon dates from Tikal and the Maya calendar correlation problem. American 
Antiquity 30:421-7.

Ralph EK. 1971. Carbon-14 dating. In: Michael HN, Ralph EK, editors. Dating Techniques for the Archaeologist. Cambridge: Massachusetts Institute of Technology Press. p 1-48.

Renfrew C. 1974. Before Civilization: The Radiocarbon Revolution and Prehistoric Europe. New York: A.A. Knopf.

Renfrew C, Bahn P. 2007. Archaeology Essentials: Theories, Methods, and Practice. London: Thames \& Hudson.

Renfew C, McMahon A, Trask L. 2000. Time Depth in Historical Linguistics. Cambridge: The McDonald Institute for Archaeological Research.

Rice DG. 1972. The Windust phase in lower Snake River region prehistory. Reports of Investigations, No. 50. Pullman: Washington State University Laboratory of Anthropology.

Riley TJ, Walz GR, Baries CJ, Fortier AC, Parker K. 1994. Accelerator mass spectrometry (AMS) dates confirm early Zea mays in the Mississippi River Valley. American Antiquity 59:490-8.

Ritchie WA. 1969. The Archaeology of New York State. Garden City: Natural History Press.

Roberts FHH. 1951. Radiocarbon dates and early man. In: Johnson F, assembler. Radiocarbon Dating. Society for American Archaeology Memoirs 8:20-1. [American Antiquity 17(1) part 2].

Robinson SW, Thompson G. 1981. Radiocarbon corrections for marine shell dates with application to southern Pacific Northwest Coast prehistory. Syesis 14:4557.

Rohn AH. 1978. American Southwest. In: Taylor RE, Meighan CW, editors. Chronologies in New World Archaeology. New York: Academic Press. p 51-70.

Roosevelt AC, Lima da Costa M, Lopes Machado C, Michab M, Mercier N, Valladas H, Feathers J, Barnett W, Imazio da Silveira M, Henderson A, Sliva J, Chernoff B, Reese DS, Holman JA, Toth N, Schick K. 1996. Paleoindian cave dwellers in the Amazon: the peopling of the Americas. Science 272(5260):373-84.

Ruben S, Kaman MD. 1941. Long-lived $\mathrm{C}^{14}$. Physical Review 59:349-54.

Santos GM, Bird MI, Pilans B, Fifield LK, Alloway BV, Chappell J, Hausladen PA, Arneth A. 2001. Radiocarbon dating of wood using different pretreatment procedures: application to the chronology of Rotoehu Ash, New Zealand. Radiocarbon 43(2A):239-48.

Santos GM, Bird MI, Parenti F, Fifield LK, Guidon N, Hausladen PA. 2003. A revised chronology of the lowest occupation layer of Pedra Furada Rock Shelter, Piauí, Brazil: the Pleistocene peopling of the Americas. Quaternary Science Reviews 22(21-22):2303-10.

Santos GM, Southon JR, Griffin S, Beaupre SR, Druffel ERM. 2007. Ultra small-mass AMS ${ }^{14} \mathrm{C}$ samples preparation and analyses at KCCAMS/UCI facility. $\mathrm{Nu}$ clear Instruments and Methods in Physics Research B 259(1):293-302.
Satterthwaite L, Ralph EK. 1960. New radiocarbon dates and the Maya correlation problem. American Antiquity 26:165-84.

Schmits KR. 2004. A review of bioarchaeological thought on the peopling of the New World. In: Barton $\mathrm{CM}$, Colar GA, Yesner DR, Pearson GA, editors. The Settlement of the American Continents: A Multidisciplinary Approach to Human Biogeography. Tucson: University of Arizona Press. p 64-75.

Schuiling WC, editor. 1972. Pleistocene Man at Calico. Redlands: San Bernardino County Museum Association.

Schurr TG. 2004. The peopling of the New World: perspectives from molecular anthropology. Аnnual Review of Anthropology 33:551-83.

Schurr TG. 2008. The peopling of the Americas as revealed by molecular genetic studies. In: Cooper DN, Kehrer-Sawatzki H, editors. Handbook of Human Molecular Evolution. New York: Wiley. p 534-56.

Shutler Jr R. 1967. Introduction, acknowledgements, staff and advisory committee. In: Wormington HM, Ellis D, editors. Pleistocene Studies in Southern $\mathrm{Ne}$ vada. Nevada State Museum Anthropological Papers, No. 13. Carson City: Nevada State Museum. p 3-13.

Simmons AH. 1986. New evidence for the early use of cultigens in the American southwest. American Antiquity 51:73-89.

Sinkin T, Siebert L. 1994. Volcanoes of the World. Tucson: Geoscience Press.

Southon JR, Brown TA. 1995. The GISP2 ice core record of volcanism since 7000 BC: comment. Science 267(5195):256-7.

Southon JR, Nelson DE, Vogel JS. 1990. A record of past ocean-atmosphere radiocarbon differences from the Northeast Pacific. Paleoceanography 5(2):197-206.

Stafford TW. 1994. Accelerator C-14 dating of human fossil skeletons: assessing accuracy and results on New World specimens. In: Bonnichsen R, Steele DG, editors. Method and Theory for Investigating the Peopling of the Americas. Corvallis: Center for the Study of the First Americans, Oregon State University. p 4556.

Stafford TW, Duhamel RC, Haynes Jr CV, Brendel K. 1982. The isolation of proline and hydroyproline from fossil bone. Life Science 31:931-8.

Stafford TW, Hare PE, Currie L, Jull AJT, Donahue DJ. 1990. Accuracy of North American human skeleton ages. Quaternary Research 34(1):111-20.

Stafford TW, Hare PE, Currie L, Jull AJT, Donahue DJ. 1991. Accelerator radiocarbon dating at the molecular level. Journal of Archaeological Science 18(1):35-72.

Stanford DJ. 1982. A critical review of archaeological evidence relating to the antiquity of human occupation of the New World. Smithsonian Contributions to Anthropology 30:202-18.

Steele DG, Powell JF. 1992. The peopling of the America: the paleobiological evidence. Human Biology 63: 301-36. 
Steele J, Politis G. 2009. AMS ${ }^{14} \mathrm{C}$ dating of early human occupation of southern South America. Journal of Archaeological Science 36(2):419-29.

Stoltman J. 1978. Temporal models in prehistory: an example from eastern North America. Current Anthropology 19:703-46.

Stuiver M. 1970. Long-term $\mathrm{C}^{14}$ variations. In: Olsson IU, editor. Radiocarbon Variations and Absolute Chronology. Stockholm: Almqvist \& Wiksell. p 197213.

Stuiver M, Polach H. 1977. Discussion: reporting of ${ }^{14} \mathrm{C}$ data. Radiocarbon 19(3):355-63.

Stuiver M, Pearson GW, Braziunas T. 1986. Radiocarbon age calibration of marine samples back to $9000 \mathrm{cal} \mathrm{yr}$ BP. Radiocarbon 28(2B):980-1021.

Stuiver M, Reimer PJ, Braziunas TF. 1998. High-precision radiocarbon age calibration for terrestrial and marine samples. Radiocarbon 40(3):1127-51.

Suess HE. 1961. Secular changes in the concentration of atmospheric radiocarbon. In: Problems Related to Interplanetary Matter. Nuclear Science Series Report Number 33, Publication 845. Washington, DC: National Academy of Sciences-National Research Council. p 90-5.

Suess HE. 1965. Secular variations of the cosmic-rayproduced carbon 14 in the atmosphere and their interpretations. Journal of Geophysical Research 70(23): 5937-52.

Swadesh M. 1952. Lexico-statistic dating of prehistoric ethnic contacts. Proceedings of the American Philosophical Society 96:453-63.

Tagg MD. 1996. Early cultigens from Fresnal Shelter, southeastern New Mexico. American Antiquity 61: $311-24$.

Tankersley KB. 1997. Keeping track of time: dating Monte Alegre and the peopling of South America. The Review of Archaeology 18:28-34.

Tankersley KB, Munson CA. 1992. Comments on the Meadowcroft Rockshelter radiocarbon chronology and the recognition of coal contaminants. American Antiquity 57:321-6.

Taylor RE. 1975. UCR radiocarbon dates II. Radiocarbon 17(3):396-406.

Taylor RE. 1978. Radiocarbon dating: an archaeological perspective. In: Carter GF, editor. Archaeological Chemistry II. Washington, DC: American Chemical Society. p 33-69.

Taylor RE. 1987. Radiocarbon Dating: An Archaeological Perspective. Orlando: Academic Press.

Taylor RE. 1991. Frameworks for dating the late Pleistocene peopling of the Americas. In: Dillehay TD, Meltzer DJ, editors. The First Americans: Search and Research. Boca Raton: CRC Press. p 77-112.

Taylor RE. 1992. Radioisotope dating by accelerator mass spectrometry: archaeological and paleoanthropological perspectives. In: Goksu HY, Obserhofer M, Regulla D, editors. Scientific Dating Methods. Dordrecht: Kluwer Academic Publishers. p 37-54.
Taylor RE. 1994a. Radiocarbon dating of bone using accelerator mass spectrometry: current discussions and future directions. In: Bonnichsen R, Steele DG, editors. Method and Theory for Investigating the Peopling of the Americas. Corvallis: Oregon State University, Center for the Study of the First Americans. p 2744.

Taylor RE. 1994b. Archaeometry of the Calico site. The Review of Archaeology 15:1-8.

Taylor RE. 1997. Radiocarbon dating. In: Taylor RE, Aitken MJ, editors. Chronometric Dating in Archaeology. New York: Plenum Press. p 65-96.

Taylor RE. 2000a. The contribution of radiocarbon dating to New World archaeology. Radiocarbon 42(1):121.

Taylor RE. 2000b. The introduction of radiocarbon dating in American archaeology. In: Nash SE, editor. $\mathrm{Ar}$ chaeological Dating and the History of North American Archaeology. Salt Lake City: University of Utah Press. p 84-104.

Taylor RE. 2001. Amino acid composition and stable carbon isotope values on Kennewick skeleton bone. Attachment B. Archeology \& Ethnography Program, National Park Service, US Department of Interior. http://www.nps.gov/archeology/Kennewick/ Taylor2.htm.

Taylor RE. 2006. Radiocarbon dating in America. Paper presented at $2^{\circ}$ Simposio Internacional "El Hombre Temprano en America." Mexico City: Instituto Nacional de Antropología e Historia.

Taylor RE, Berger R. 1967. Radiocarbon content of marine shells from the Pacific coasts of Central and South America. Science 158(3805):1180-2.

Taylor RE, Berger R. 1968. Radiocarbon dating of the organic portion of ceramic and wattle-and-daub house construction materials of low carbon content. American Antiquity 33:363-6.

Taylor RE, Payen LA, Gerow B, Donahue DJ, Zabel TH, Jull AJT, Damon PE. 1983. Middle Holocene age of the Sunnyvale human skeleton. Science 220(4603): 1271-3.

Taylor RE, Payen LA, Prior CA, Slota Jr PJ, Gillespie R, Gowlett JAJ, Hedges REM, Jull AJT, Zabel TH, Donahue DJ, Berger R. 1985. Major revisions in the Pleistocene age assignments for North American human skeletons by ${ }^{14} \mathrm{C}$ accelerator mass spectrometry: none older than $11,000{ }^{14} \mathrm{C}$ years B.P. American Antiquity 50:136-40.

Taylor RE, Payen LA, Slota Jr PJ. 1992. The age of the Calaveras Skull: dating the "Piltdown Man" of the New World. American Antiquity 57:269-75.

Taylor RE, Hare PE, Prior CA, Kirner DL, Wan L, Burky RR. 1995. Radiocarbon dating of biochemically characterized hair. Radiocarbon 37(2):319-30.

Taylor RE, Haynes Jr CV, Stuiver M. 1996. Clovis and Folsom age estimates: stratigraphic context and radiocarbon calibration. Antiquity 70(269):515-25.

Taylor RE, Kirner DL, Southon JR, Chatters JC. 1998. 
Radiocarbon dates of Kennewick Man. Science 280(5367):1171-2.

Taylor RE, Haynes Jr CV, Kirner DL, Southon JR. 1999. Analysis of modern organics at Monte Verde, Chile: no evidence for a local reservoir effect. American Antiquity 64:455-60.

Taylor RE, Smith D, Southon JR. 2001. The Kennewick skeleton: chronological and biomolecular contexts. Radiocarbon 43(2B):965-76.

Thomas DH. 2000. Skull Wars: Kennewick Man, Archaeology, and the Battle for Native American Identity. New York: Basic Books.

Thompson JES. 1971. Maya Hieroglyphic Writing: An Introduction. 3rd edition. Norman: University of Oklahoma Press.

Unkel I, Kromer B, Reindel M, Wacker L, Wagner G. 2007. A chronology of the pre-Columbian Paracas and Nasca cultures in south Peru based on AMS ${ }^{14} \mathrm{C}$ dating. Radiocarbon 49(2):551-64.

Wakeley LD, Murphy WL, Dunbar JB, Warne AG, Briuer FL, Nickens PR. 1998. Geologic, geoarchaeologic, and historical investigation of the discovery site of ancient remains in Columbia Park, Kennewick, Washington. Technical Report GL-98-13, Vicksburg: US Army Corps of Engineers Waterways Experiment Station.

Walter HV, Cathoud A, Mattos A. 1937. The Confins Man, a contribution to the study of early man in South America. Symposium on Early Man. Philadelphia: Academy of Science of Philadelphia. p 141-8.

Walton A, Trautman MA, Friend JP. 1961. Isotopes, Inc. radiocarbon measurements I. Radiocarbon 3:47-59.
Waters MR, Stafford Jr TW. 2007. Redefining the age of Clovis: implications for the peopling of the Americas. Science 315(5815):1122-6.

Willey GR. 1978. A summary scan. In: Taylor RE, Meighan CW, editors. Chronologies in New World Archaeology. New York: Academic Press. p 513-64.

Willey GR, Phillips P. 1958. Method and Theory in American Archaeology. Chicago: University of Chicago Press.

Willis EH, Tauber H, Munnich KO. 1960. Variations in the atmospheric radiocarbon concentration over the past 1300 years. Radiocarbon 2:1-4.

Wilmsen EN. 1965. An outline of early man studies in the United States. American Antiquity 31:172-92.

Wormington HM. 1957. Ancient Man in North America. Denver: Denver Museum of Natural History.

Wormington HM, Ellis D. editors. 1967. Pleistocene Studies in Southern Nevada. Nevada State Museum Anthropological Papers, No. 13. Carson City: Nevada State Museum.

Yang S-H. 1993. Radiocarbon dating and American evangelical Christians. Perspectives on Science \& Christian Faith 45:229-40.

Yohe RM. 1992. A reevaluation of Western Great Basin culture chronology and evidence for the timing of the introduction of the bow and arrow to eastern California based on new excavations at the Rose Spring site (CA-INY-372) [PhD dissertation]. University of California, Riverside.

Zdanowicz CM, Zielinski GA, Germani MS. 1999. Mount Mazama eruption: calendrical age verified and atmospheric impact assessed. Geology 27:621-4. 